Policy Research Working Paper 2002

\section{Accounting for Toxicity Risks in Pollution Control}

\author{
Does It Matter?
}

Susmita Dasgupta

Benoît Laplante

Craig Meisner
It is important for

environmental regulators to

weight pollutants for their

relative toxicity risk when

developing priorities for

pollution control efforts at the industrial or regional level.

But at high levels of

aggregation, the choice of

indicator need not be the

subject of immense debate.

The World Bank

Development Research Group Environment and Infrastructure

November 1998 
Policy Research Working Paper 2002

\section{Summary findings}

The accounting and public release of information about industrial toxic pollution emissions is meeting increasing criticism in that these listings typically do not account for the different toxicity risks associated with different pollutants. A firm emitting a large amount of a relatively harmless substance is ranked as a heavier polluter than a firm emitting a small quantity of a potent substance.

Such "unweighted" rankings of firms, it is argued, may lead to a misallocation of resources and a wrong prioritization of efforts in pollution control. This is a particular problem in developing countries, where sources for pollution control are typically scarce.

To account for varying toxicity risk, a number of organizations have developed thresholds or exposure limits for various pollutants. But many toxicity risk factors and methods are currently available, and different risk indicators yield different results and hence priorities.

So Dasgupta, Laplante, and Meisner review seven risk methods and construct 10 sets of toxicity risk factors from those indicators. They apply those factors to the 3,426 industrial municipalities of Brazil and explore Rio de Janeiro and São Paulo in detail.

After ranking states and municipalities for their pollution intensity, results indicate that at the state level, risk-weighted rankings remain largely the same across the 10 sets of toxicity risk factors used in this paper. By and large the result also holds true at the municipal level.

Although at the state level the unweighted ranking is relatively similar to the risk-weighted ranking, at the municipal level significant differences were found between the risk-weighted and unweighted rankings.

These findings suggest that it is important for environmental regulators to weight pollutants for their relative toxicity risk when developing priorities for pollution control efforts at the industrial or regional level. But at high levels of aggregation, the choice of indicator need not be the subjecr of immense debate.

This paper - a product of Environment and Infrastructure, Development Research Group - is part of a larger study on industrial pollution. Copies of this paper are available free from the World Bank, $1818 \mathrm{H}$ Street NW, Washington, DC 20433. Please contact Yasmin D'Souza, room MC2-622, telephone 202-473-1449, fax 202-522-3230, Internet address ydsouza@worldbank.org. Susmita Dasgupta may be contacted at sdasgupta@worldbank.org. November 1998. (36 pages)

The Policy Research Working Paper Series disseminates the findings of work in progress to encourage the exchange of ideas about development issues. An objective of the series is to get the findings out quickly, even if the presentations are less than fully polished. The papers carry the names of the authors and should be cited accordingly. The findings, interpretations, and conclusions expressed in this paper are entirely those of the authors. They do not necessarily represent the view of the World Bank, its Executive Directors, or the countries they represent. 


\title{
ACCOUNTING FOR TOXICITY RISKS IN POLLUTION CONTROL: DOES IT MATTER?
}

\author{
By \\ Susmita Dasgupta \\ Benoit Laplante \\ and \\ Craig Meisner
}

\begin{abstract}
The World Bank
Development Research Group

Environment \& Infrastructure
\end{abstract}

For correspondence, communicate with: Susmita Dasgupta, Development Research Group, The World Bank, 1818 H Street, N.W., Washington, D.C. 20433; or at sdasgupta@worldbank.org. 


\section{Acknowledgments}

We would like to thank the researchers at the Instituto Brasileiro de Geografia e Estatísticsa (IBGE) in Brazil who supplied us with the data necessary to conduct this analysis. Our most sincere thanks to Manjula Singh and Mala Hettige for their work with the Industrial Pollution Projection System. Finally we thank Mr. David Wheeler of the Development Research Group of the World Bank for his comments. Usual disclaimers apply. 


\section{Executive Summary}

The accounting and public release of information pertaining to industrial toxic pollution emissions is meeting increasing criticism in that these listings typically do not account for the different toxicity risks associated with different pollutants: A firm emitting a large quantity of a relatively harmless substance would rank as a larger polluter than another firm emitting a small quantity of a very potent substance. It is argued that such "unweighted" rankings of firms may lead to a misallocation of resources and wrong prioritization of effort devoted to pollution control. This may be of particular importance for developing countries where resources devoted to pollution control are typically scarce.

In an attempt to account for the relative differences in chemical toxicity, a number of organizations have developed thresholds or exposure limits for various pollutants to account for their various toxicity risk. Given the large number of toxicity risk factors and methodologies currently available, a crucial issue pertains to the possibility that different risk indicators may yield different results, thus leading to different sets of priorities. In this paper, we review seven risk methodologies currently available, and construct 10 different sets of toxicity risk factors from these indicators. We then apply these factors to the 3426 industrialized municipals of Brazil; we further explore in more detail, the case of Rio de Janeiro and São Paulo. Upon ranking states and municipals for their pollution intensity, results indicate that at the state level, risk weighted rankings remain largely the same across the 10 different sets of toxicity risk factors used in this paper. This result by and large also holds true at the municipal level. Moreover, at the state level, the unweighted ranking is relatively similar to the risk weighted ranking. However, at the municipal level, significant differences were found between the risk weighted and unweighted rankings.

These findings suggest that it is of importance for environmental regulators to engage into weighting pollutants for their relative toxicity risk when prioritizing pollution control effort either at the industrial or regional level. The findings however suggest that at high levels of aggregation, the choice of a particular indicator should not be a matter of immense debate. 


\section{Introduction}

An increasing number of environmental regulators in developed and developing countries have embarked on programs to account for the release of toxic pollution by industrial firms. Some of these programs also involve the public release of the information thus collected from industrial polluters. An example of such a program is the Toxics Release Inventory (TRI) published annually by the United States Environmental Protection Agency. These listings are meeting an increasing amount of criticism in that they typically do not account for the different toxicity risk associated with different pollutants: A firm emitting a large quantity of a relatively harmless substance would rank higher than another firm emitting a small quantity of a very potent substance. It is argued that such "unweighted" rankings of firms may lead to a misallocation of resources and wrong prioritization of effort devoted to pollution control. To the extent that the information is publicly available, it may also lead to a false sense of security, or alarm. Indeed, results from previous applications of risk-weighting factors have been significantly different than priority rankings based solely on volume-based techniques which do not account for the heterogeneous risk of pollutants. ${ }^{1}$

Acknowledging these differences in chemical toxicity, a number of organizations have developed indices, based on alternative methodologies, to weigh pollutants to account for their relative toxicity risk. Given the large number of indicators currently

Swanson et al. (1997). 
available, a recurring concern and crucial issue for environmental regulators pertains to the possibility that different methodologies may yield different results, and indicate different sets of priorities. This may be of particular importance for environmental regulators of developing countries where resources devoted to pollution control are typically scarce.

In this paper, we review seven indicators currently available and from these construct ten different sets of toxicity risk factors. We then apply these toxicity risk factors to the 3426 industrialized municipals of Brazil, ${ }^{2}$ and discuss in more detail the estimates obtained for São Paulo and Rio de Janeiro (henceforth Rio). Our findings suggest that it is of importance for environmental regulators to engage into weighing pollutants for their relative risk factors when prioritizing pollution control effort. The findings however suggest that the choice of a particular risk indicator should not be a matter of immense debate as the relative impact of different risk indicators appears to be small for the prioritization of pollution control effort at high levels of industrial aggregation.

In the next section, we describe the risk exposure indicators chosen for analysis in this paper, and for each index indicate how the relative risk factors were constructed. In Section III, we apply these factors to Brazil and focus more specifically on Rio and São

2 There were a total of 4974 municipals as of August 31, 1995; 3426 of these presented some degree of industrialization (IBGE, Directoria de Geociências, Departamento de Estudos Territoriais, 1995). 
Paulo. We first provide a brief description of the Brazilian industrial and environmental regulatory contexts. We then estimate toxic pollution emissions for each industry and region of Brazil with the help of the Industrial Pollution Projection System. Finally, we apply the various sets of toxicity risk factors to these pollution estimates. We briefly conclude in Section IV.

\section{Risk weighting methodologies and risk factors}

(i) Risk weighting methodologies

In both developing and developed countries, risk assessment has recently become an integral component of the formulation of pollution regulation. In a context of limited resources, the identification and prioritization of intervention (defined in terms of industrial sectors or geographical areas) based on an assessment of risk is imperative for the reduction of toxic-related health problems. In the United States for example, various governmental and non-governmental organizations, such as the Environmental Protection Agency (EPA) and the American Conference of Governmental Industrial Hygienists (ACGIH) regularly publish comprehensive lists of hazardous chemicals which may serve as guidelines for explicitly incorporating toxic risk in the prioritization of pollution control effort. However, each of these organizations follows its own method of classifying chemical hazards or risk, where the choice of an indicator is for the most part dictated by regulatory requirements. For the purpose of the current comparative analysis, our interest lies not only in comparing risk-weighted and unweighted rankings of pollution intensive areas, but also to compare the risk weighted rankings under alternative measures of risk (such as short term vs long term exposure). 
In Table 1, we list seven widely recognized toxicity indices along with the organization using these indices. The classification enforceable / non-enforceable indicates whether or not the index is enforceable by law.

Table 1 Toxicity indices

\begin{tabular}{||l|l|l||}
\hline \multicolumn{1}{|c|}{ Source } & \multicolumn{1}{|c|}{ Index name } & Classification \\
\hline $\begin{array}{l}\text { American Conference of Governmental } \\
\text { Industrial Hygienists (ACGIH) }\end{array}$ & Threshold Limit Values (TLV) & $\begin{array}{l}\text { Medium-term } \\
\text { Non-enforceable }\end{array}$ \\
\hline $\begin{array}{l}\text { U.S. Department of Labor, Occupational Safety } \\
\text { and Health Administration (OSHA) }\end{array}$ & $\begin{array}{l}\text { Permissible Exposure Limits } \\
\text { PEL) }\end{array}$ & $\begin{array}{l}\text { Medium-term } \\
\text { Enforceable }\end{array}$ \\
\hline $\begin{array}{l}\text { National Institute for Occupational Safety and } \\
\text { Health (NIOSH) }\end{array}$ & $\begin{array}{l}\text { Recommended Exposure Limits } \\
\text { (REL) }\end{array}$ & $\begin{array}{l}\text { Medium-term } \\
\text { Enforceable }\end{array}$ \\
\hline $\begin{array}{l}\text { Deutsche Forschungsgemeinschaft } \\
\text { (DFG, Federal Republic of Germany) }\end{array}$ & $\begin{array}{l}\text { Maximum Concentration Values } \\
\text { in the Workplace (MAK) }\end{array}$ & $\begin{array}{l}\text { Medium-term } \\
\text { Enforceable }\end{array}$ \\
\hline $\begin{array}{l}\text { Santa Clara Center for Occupational Safety and } \\
\text { Health (SCCOSH) }\end{array}$ & $\begin{array}{l}\text { Health-Based Exposure Limits } \\
\text { (HBEL) }\end{array}$ & $\begin{array}{l}\text { Long-term } \\
\text { Non-enforceable }\end{array}$ \\
\hline $\begin{array}{l}\text { U.S. Department of Energy, Subcommittee on } \\
\text { Consequence Assessment and Protective } \\
\text { Action (SCAPA) }\end{array}$ & $\begin{array}{l}\text { Temporary Emergency Exposure } \\
\text { Limits (TEEL) }\end{array}$ & $\begin{array}{l}\text { Short-term } \\
\text { Enforceable* }\end{array}$ \\
\hline $\begin{array}{l}\text { U.S. Environmental Protection Agency, Sector } \\
\text { Facility Indexing Project (SFIP) }\end{array}$ & $\begin{array}{l}\text { Toxics Release Inventory } \\
\text { Indicators toxicity weights (TRI } \\
\text { toxicity weights) }\end{array}$ & $\begin{array}{l}\text { Long-term } \\
\text { Non-enforceable }\end{array}$ \\
\hline
\end{tabular}

TEEL are enforceable only on U.S. Department of Energy sites.

In Table 2, we provide a brief definition of each index. Note that TLV, PEL, REL, and MAK all have the same definition. However, while PEL, REL and MAK have all been largely adopted from TLV, the number of chemicals covered by each index is different. Moreover, PEL, REL and MAK are enforceable by law whereas TLV act only as recommendations. TLV, PEL, REL and MAK have been broadly classified as medium term since exposure is defined as a time-weighted average per working day and / or working week with the number of years of exposure not being explicitly referred to (i.e. versus chronic or lifetime exposure). 
Two other indicators, HBEL and TEEL, are of interest as they define polar extremes of relative toxicity: HBEL are maximum lifetime daily exposure concentrations, while TEEL can be interpreted as maximum short term exposure concentrations. The last indicator, the U.S. EPA TRI toxicity weighting system, is a new initiative by the EPA to address public criticism that the TRI inventory has been purely based on volumes of emissions. ${ }^{3}$ This very recent development of risk incorporation into the TRI accounting of chemical loads is a valuable opportunity for the purpose of the current exercise.

\section{(ii) Risk factors}

In order to incorporate risk into the analysis, we must aggregate the releases of various industrial pollutants within a specific region. In order to do so, we must initially convert each chemical into equivalent weights for each of the ten sets of toxicity indicators presented in Table 2 . These weights were calculated by normalizing each chemical with respect to a reference chemical, chosen to be sulfuric acid:

$$
\mathrm{w}_{\mathrm{ij}}=\frac{(\text { Reference value for sulfuric acid provided by index } \mathrm{j})}{\text { (Reference value of chemical i provided by index } \mathrm{j})}
$$

where $\mathrm{w}_{\mathrm{ij}}$ is the sulfuric acid equivalent risk factor associated with chemical $\mathrm{i}$ upon using toxicity index $j(j=1$ to 10$){ }^{4}$

3 The TRI is understood as being one of the largest sources of environmental information available to the public (Hamilton, 1995; Konar and Cohen, 1997).

4 For example, suppose there are three pollutants A, B, and C, with pollutant A representing sulfuric acid. Each of the 10 indices provides a threshold or exposure limit for pollutants $A, B$ and $C$. Let the limits provided by index $j$ be $R_{A j}, R_{B j}$, and $R_{C j}$ respectively. Then, $w_{A j}$ would be $R_{A j} / R_{A j}$ or $1, w_{B j}$ would be $R_{\mathrm{Aj}} / R_{\mathrm{Bj}}$ and $w_{\mathrm{Cj}}$ would be $\mathrm{R}_{\mathrm{Aj}} / R_{\mathrm{Cj}}$. 
Let $\mathrm{Q}_{\mathrm{ix}}$ be the estimated (unweighted) pollution load of chemical $\mathrm{i}$ in region $\mathrm{x}$. Then,

$$
\mathrm{Q}_{\mathrm{ix}} \bullet \mathrm{w}_{\mathrm{ij}}
$$

gives the estimated risk weighted releases of pollutant $i$ (in sulfuric acid equivalent) in region $\mathrm{x}$ upon using index $\mathrm{j}$. Aggregating over all pollutants yields:

(3) $\quad P_{x j}=\sum_{i=1}^{n} Q_{i x} \cdot w_{i j}$

where $P_{x j}$ is the estimated total risk weighted releases of pollution in region $x$ upon using index $\mathrm{j}$, and $\mathrm{n}$ is the number of chemicals covered by index $\mathrm{j}$.

\section{Estimates of risk weighted pollution load in Brazil}

\section{(i) The Brazilian context}

The industrial sector in Brazil accounts presently for nearly 35\% of GDP, and represents a significant share of the total working population, across the five major regions of Brazil (Table 3). However, the relative importance of industrial activity across Brazilian states varies considerably and in some regions represents a very significant share of total employment. As can be seen in Table 4, manufacturing employment as a percentage of the total working population is quite high in such states as São Paulo and Rio de Janeiro. These highly industrialized states (with the exception of the Distrito Federal) also enjoy a higher GDP per head while less industrialized states lag far behind (Table 5). Within the manufacturing sector, some the largest employers are in the wearing apparel, motor vehicle, metal and textile industrial sectors (Table 6). 
Table 2

\section{Description of index}

\begin{tabular}{|c|c|}
\hline Index & Description \\
\hline $\begin{array}{l}1997 \text { ACGIH Threshold Limit Values } \\
\text { (TLV) }\end{array}$ & $\begin{array}{l}\text { Time-weighted average (TWA) exposure concentration that cannot be exceeded for a conventional 8-hour workday and a } \\
\text { 40-hour workweek. }\end{array}$ \\
\hline $\begin{array}{l}\text { 1993-97 OSHA Permissible Exposure } \\
\text { Limits (PEL) }\end{array}$ & TWA exposure concentration that cannot be exceeded for a conventional 8-hour workday and a 40-hour workweek. \\
\hline $\begin{array}{l}1994 \text { NIOSH Risk Exposure Limits } \\
\text { (REL) }\end{array}$ & TWA exposure concentration that cannot be exceeded for a conventional 8-hour workday and a 40-hour workweek. \\
\hline 1996 DFG (MAK) & TWA exposure concentration that cannot be exceeded for a conventional 8-hour workday and a 40 -hour workweek. \\
\hline $\begin{array}{l}1995 \text { SCCOSH Health-Based Exposure } \\
\text { Limits (HBEL - Non-Cancer) }\end{array}$ & Maximum lifetime daily exposure concentration for a conventional 8-hour workday, 240 -days/year, for 40 years. \\
\hline $\begin{array}{l}1998 \text { U.S. DOE SCAPA Temporary } \\
\text { Emergency Exposure Limits (TEEL-0) }\end{array}$ & $\begin{array}{l}\text { Derived mostly from TLV-STEL and PEL-STEL. A 15-minute time-weighted average exposure concentration that } \\
\text { should not be exceeded at any time during the workday. }\end{array}$ \\
\hline $\begin{array}{l}1998 \text { U.S. DOE SCAPA Temporary } \\
\text { Emergency Exposure Limits (TEEL-1) }\end{array}$ & $\begin{array}{l}\text { Derived mostly from TLV-C and PEL-C. A time-weighted average concentration that is not to be exceeded during any } \\
\text { part of the working exposure. }\end{array}$ \\
\hline $\begin{array}{l}1998 \text { U.S. DOE SCAPA Temporary } \\
\text { Emergency Exposure Limits ('TEEL-2) }\end{array}$ & $\begin{array}{l}\text { Measure of toxicity (TCLo and TDLo) estimated from human or human-equivalent toxicity data from Sax's Dangerous } \\
\text { Properties of Industrial Materials (1996/97) with a maximum of } 500 \mathrm{mg} / \mathrm{m}^{3} \text { for particulate materials, if no hierarchy- } \\
\text { based values could be estimated using methodology outlined in NIOSH (1994). }\end{array}$ \\
\hline $\begin{array}{l}1998 \text { U.S. DOE SCAPA Temporary } \\
\text { Emergency Exposure Limits (TEEL-3) }\end{array}$ & $\begin{array}{l}\text { Measure of lethality (LCLo, LDLo, and LD50) estimated from human or human-equivalent toxicity data from Sax's } \\
\text { Dangerous Properties of Industrial Materials (1996/97) with a maximum of } 500 \mathrm{mg} / \mathrm{m}^{3} \text { for particulate materials, if no } \\
\text { hierarchy-based values could be estimated using methodology outlined in NIOSH (1994). }\end{array}$ \\
\hline $\begin{array}{l}1998 \text { U.S. EPA SFIP TRI Relative Risk- } \\
\text { Based Chronic Human Health Indicator } \\
\text { Toxicity Weights (TRI Toxicity } \\
\text { Weights) }\end{array}$ & $\begin{array}{l}\text { A chronic human health proportional weighting system utilizing Reference Dose values (RfD) for cancer and non-cancer } \\
\text { effects, along with weight-of-evidence measures for carcinogens. RfDs are derived from a combination of NOAEL, } \\
\text { LOAEL, uncertainty factors in intraspecies variability, interspecies extrapolation and extrapolation from subchronic to } \\
\text { chronic data. }\end{array}$ \\
\hline \multicolumn{2}{|c|}{$\begin{array}{ll}\text { Note: } & \text { STEL - Short-Term Exposure Limit; C - Ceiling limit; TCLo - Toxic Concentration Low; TDLo - Toxic Dose Low; } \\
& \text { LCLo - Lethal Concentration Low; LDLo - Lethal Dose Low; LD50 - Lethal Dose Fifty; NOAEL - No Observable Adverse Effect Level; } \\
& \text { LOAEL - Lowest Observable Adverse Effect Level }\end{array}$} \\
\hline
\end{tabular}


Table 3: Industrial employment per region, 1993

\begin{tabular}{|c|c|c|c|}
\hline Region & $\begin{array}{c}\text { Total Working } \\
\text { Population }\end{array}$ & $\begin{array}{c}\text { Industrial } \\
\text { Employment }{ }^{(1)}\end{array}$ & $\begin{array}{l}\text { \% Employed in } \\
\text { Industry }\end{array}$ \\
\hline Sudeste (2) & 28700970 & 7305969 & 25.46 \\
\hline Sul (3) & 11560445 & 2535344 & 21.93 \\
\hline Norte ${ }^{(4)}$ & 2555088 & 490426 & 19.19 \\
\hline Centro-oeste ${ }^{(s)}$ & 4601976 & 704640 & 15.31 \\
\hline Nordeste ${ }^{(6)}$ & 18968726 & 2724173 & 14.36 \\
\hline
\end{tabular}

(1) - Industry includes the construction sector.

(2) - Sudeste includes: Minas Gerais, Espirito Santo, Rio de Janeiro, São Paulo.

(3) - Sul includes: Paraná, Santa Catarina, Rio Grande do Sul.

(4) - Norte includes: Rondônia, Acre, Amazonas, Roraima, Pará, Amapá, Tocantins.

(5) - Centro-oeste includes: Mato Grosso do Sul, Mato Grosso, Goiás, Distrito Federal.

(6) - Nordeste includes: Maranhão, Piauí, Ceará, Rio Grande do Norte, Paraíba, Pemambuco, Alagoas, Sergipe, Bahia.

Table 4: Level of manufacturing employment, 1994

\begin{tabular}{||l|r|r|r||}
\hline \multicolumn{1}{|c|}{ State } & $\begin{array}{c}\text { Manufacturing } \\
\text { Employment (1) }\end{array}$ & $\begin{array}{c}\text { Population of } \\
\text { Working Age (2) }\end{array}$ & $\begin{array}{c}\text { \% of Working Population } \\
\text { in Manufacturing }\end{array}$ \\
\hline \hline Santa Catarina & 313259 & 2757602 & 11.36 \\
\hline São Paulo & 2082706 & 19789464 & 10.52 \\
\hline Rio Grande do Sul & 494381 & 5528990 & 8.94 \\
\hline Paraná & 273241 & 4784951 & 5.71 \\
\hline Minas Gerais & 421575 & 9000056 & 4.68 \\
\hline Rio de Janeiro & 364493 & 7783014 & 4.68 \\
\hline Pernambuco & 136808 & 3756185 & 3.64 \\
\hline Alagoas & 46871 & 1327357 & 3.53 \\
\hline Espírito Santo & 53506 & 1543563 & 3.47 \\
\hline Amazonas & 34404 & 1158283 & 2.97 \\
\hline Ceará & 93484 & 3330191 & 2.81 \\
\hline Mato Grosso do Sul & 24346 & 1057585 & 2.30 \\
\hline Goí́s & 53221 & 2423371 & 2.20 \\
\hline Rio Grande do Norte & 28175 & 1320106 & 2.13 \\
\hline Sergipe & 16414 & 814387 & 2.02 \\
\hline Pará & 47986 & 2749896 & 1.75 \\
\hline Paraíba & 25075 & 1607131 & 1.56 \\
\hline Mato Grosso & 16757 & 1322892 & 1.27 \\
\hline Rondônia & 9351 & 760053 & 1.23 \\
\hline Bahia & 73754 & 6271747 & 1.18 \\
\hline Distrito Federal & 11673 & 1028217 & 1.14 \\
\hline Piaú́ & 12685 & 1302481 & 0.97 \\
\hline Amapá & 1290 & 161986 & 0.80 \\
\hline Acre & 1670 & 220835 & 0.76 \\
\hline Maranhão & 16649 & 2419597 & 0.69 \\
\hline Tocantins & 2174 & 505368 & 0.43 \\
\hline Roraima & 386 & 156300 & 0.25 \\
\hline Total & 4656334 & 84881608 & 5.49 \\
\hline \hline
\end{tabular}

(1) - Source: Instituto Brasileiro de Geografia e Estatísticsa (IBGE), 1994.

(2) - Source: IBGE, Diretoria de Pesquisas, Departamento de População e Indicadores Sociais, Censos Demográficos de 1980 e 1991. Calculated as the total population between ages 17 to 60 . 
Table 5

Gross domestic product per capita, 1994

\begin{tabular}{lclc} 
Highest & $(\$)$ & Lowest & $(\$)$ \\
\hline Distrito Federal & 7080 & Paraíba & 1108 \\
\hline São Paulo & 4666 & Maranhão & 1055 \\
\hline Rio de Janeiro & 4386 & Sergipe & 958 \\
\hline Paraná & 3674 & Tocantins & 901 \\
\hline Rio Grande do Sul & 3670 & Piauí & 835 \\
\hline Source Insturo
\end{tabular}

Source: Instituto de Pesquisa Económica Aplicada (IPEA).

Table 6

Top 10 manufacturing employers

\begin{tabular}{|c|c|c|c|c|c|}
\hline \multicolumn{2}{|l|}{ Brazil } & \multicolumn{2}{|c|}{ Rio de Janeiro } & \multicolumn{2}{|l|}{ São Paulo } \\
\hline Industry & $\begin{array}{c}\text { Percentage } \\
\text { share* }^{*}\end{array}$ & Industry & $\begin{array}{c}\text { Percentage } \\
\text { share }\end{array}$ & Industry & $\begin{array}{c}\text { Percentage } \\
\text { share }\end{array}$ \\
\hline Wearing apparel & 7.75 & Wearing apparel & 12.07 & Motor vehicles & 10.57 \\
\hline Motor vehicles & 6.51 & Iron \& steel & 7.20 & Wearing apparel & 6.69 \\
\hline Footwear & 5.01 & Printing \& publishing & 7.04 & $\begin{array}{l}\text { Fabricated metal } \\
\text { products }\end{array}$ & 6.02 \\
\hline $\begin{array}{l}\text { Fabricated metal } \\
\text { products }\end{array}$ & $\overline{4.44}$ & Plastic products, N.E.C. & 4.87 & Plastic products, N.E.C. & 4.84 \\
\hline $\begin{array}{l}\text { Sugar factories \& } \\
\text { refineries }\end{array}$ & 4.32 & Drugs \& medicines & 4.26 & $\begin{array}{l}\text { Spinning, weaving \& } \\
\text { finishing textiles }\end{array}$ & 4.01 \\
\hline $\begin{array}{l}\text { Spinning, weaving \& } \\
\text { finishing textiles }\end{array}$ & 4.14 & Bakery products & 4.07 & $\begin{array}{l}\text { Electrical apparatus \& } \\
\text { supplies, N.E.C. }\end{array}$ & 3.93 \\
\hline Iron \& steel & 3.86 & $\begin{array}{l}\text { Fabricated metal } \\
\text { products }\end{array}$ & 4.03 & Printing \& publishing & 3.59 \\
\hline Plastic products, N.E.C. & 3.81 & $\begin{array}{l}\text { Shipbuilding \& } \\
\text { repairing }\end{array}$ & 3.91 & $\begin{array}{l}\text { Sugar factories \& } \\
\text { refineries }\end{array}$ & 3.12 \\
\hline $\begin{array}{l}\text { Sawmills, planing \& } \\
\text { other wood mills }\end{array}$ & 3.40 & $\begin{array}{l}\text { Spinning, weaving \& } \\
\text { finishing textiles }\end{array}$ & 3.55 & Footwear & 3.02 \\
\hline Printing \& publishing & 3.39 & $\begin{array}{l}\text { Nonmetallic mineral } \\
\text { products, N.E.C. }\end{array}$ & 2.59 & Iron \& steel & 2.76 \\
\hline
\end{tabular}

* - Percentage share of all manufacturing employment.

An unfortunate consequence of industrialization is the increasing emission of toxics to the environment, and subsequently the requirement for prioritization, regulation and control. Brazil's experience with environmental regulation has been both a success 
story, due to the significant experience of some state agencies, and a failure as a consequence of recent fiscal constraints and a lack of political support.

Environmental legislation in Brazil dates back to 1973 and was modeled mostly after the American experience, relying heavily on standards and licenses. The objectives of environmental policy are defined in terms of minimum ambient environmental standards which the Federal Government has established for air and water. Brazil's pollution control policy is centralized around a licensing system that requires a valid environmental license for every potentially polluting activity. States have implemented their own licensing systems based on the national framework. Since 1974, most States have created Environmental Protection Agencies (OEMAS - orgãos estaduais de meio ambiente) which are in charge of licensing, monitoring and enforcing environmental regulations. States have implemented different systems of fines for environmental violations; fines are normally a function of the estimated level of damages resulting from the violation. However, as in most cases, the effective implementation of those fines has proved challenging.

Municipalities are playing an increasingly important role in pollution management and are currently responsible for zoning, water, sanitation, solid waste and drainage services. In addition, larger municipalities are assuming licensing functions for activities which have the potential of being significant sources of local pollution. However, the 
administrative capacity to implement, monitor and enforce the terms of the licenses is typically limited.

Pollution control in the states of Rio and São Paulo is the responsibility of FEEMA (Fundacão Estadual de Engenharia do Meio Ambiente) and CETESB (Conpanhia de Tecnologica de Saneamento Ambiental) respectively. These two agencies have often been acknowledged as leading environmental agencies in the developing world. They are the largest state environmental agencies in Brazil with staff of 2200 and 900 , and supported budgets of approximately US\$ 90 and US\$25 million for the year 1997 respectively (World Bank, 1998). Most other state environmental agencies have much smaller staff and budgets, and have suffered a serious decline in recent years due to fiscal constraints. The larger agencies have also experienced a serious decline in their effectiveness. Environmental management in the state of Rio has deteriorated as a result of the fiscal crisis and lack of political support under previous administrations. FEEMA is paralyzed by a lack of accountability, an excessive number of poorly paid and unmotivated staff, and serious budget rigidities. It is argued that the numerous bureaucratic environmental requirements, and a serious lack of reliable environmental information and planning prevent the State environmental agencies from adequately performing its core functions.

Given the poor economic and political environment within which state environmental agencies must operate, there is a strong need for the application of tested 
methodologies in order to prioritize pollution control effort. This is especially the case for state environmental agencies which are currently preparing comprehensive restructuring and modernization plans aimed at improving their effectiveness. These plans involve an important decentralization of roles and responsibilities, while still retaining a supervisory role. To these ends, the application of tested methodologies to estimate pollution load on a regional basis can provide regulators with crucial information pertaining to areas of high pollution intensity. This is especially the case on matters of toxic emissions for which information, on a plant and / or regional level, has never been thoroughly collected in Brazil.

(ii) Estimating pollution load in Brazil

As indicated earlier, in order to estimate the total releases of (sulfuric equivalent) chemicals in Brazil, we must first obtain (unweighted) estimates of emissions of chemicals $\left(\mathrm{Q}_{\mathrm{ix}}\right.$ in equation (2)). Despite the existing legislative and institutional apparatus, it is generally recognized that Brazilian environmental authorities (like most environmental authorities of developing countries) lack the necessary information on plant-level emissions to set priorities, strategies, and action plans. This is especially the case with toxic chemicals whose releases are typically not monitored.

As a response to this insufficiency of information, Hettige et al. (1995) have developed the Industrial Pollution Projection System (IPPS) to exploit the fact that industrial pollution is heavily affected by the scale of industrial activity and its sectoral 
composition. IPPS operates through sector estimates of pollution intensity (pollution per unit of activity). The system combines data from industrial activity (such as production and employment) with data on pollution emissions to calculate pollution intensities, i.e. the level of pollution emissions per unit of industrial activity (Pollution intensity $=$ Pollution emissions / Measure of industrial activity). The model can be refined to include only chemical intensities by using information solely on chemical releases along with industrial activity (Chemical intensity $=$ Chemical emissions $/$ Measure of industrial activity).

As illustrated in Figure 1, chemical intensities have initially been calculated with data available in the United States from the U.S. Manufacturing Census and the U.S. Environmental Protection Agency (EPA). The Census maintains a database known as the Longitudinal Research Database (LRD) which contains information from the Census of Manufactures (CM) and the Annual Survey of Manufactures (ASM). While the CM contains information on all manufacturing establishments in the United States, the ASM seeks further and more detailed information on a subset of those companies. Once an establishment has been selected to be part of the ASM, information is collected from the chosen company once a year, for a period of 5 years. The LRD thus contains detailed information on approximately 200,000 plants. The EPA maintains a number of databases 
on pollution emissions including the Toxics Release Inventory (TRI), which was used to calculate chemical intensities for each industry. ${ }^{5}$

An immediate difficulty with the calculation of intensities is the measure of industrial activity. While physical volume of output would be the ideal unit of measurement, industries and even establishments within a given industry use different units to report the volume of their production, thus not allowing for comparison across industries. The value of output and plant-level employment (also contained in the LRD) however do offer such common units of measurement. Combining the LRD's database with the EPA TRI database, it was possible to calculate 329 chemical intensities for each industrial sector (at the 4 digit International Standard Industrial Classification (ISIC) level), using both the value of output and plant-level employment. ${ }^{6}$

5 At the time, the TRI contained information on annual emissions for more than 300 toxic chemicals to the environment. Manufacturing establishments that (1) employed 10 full-time employees or more and (2) produced, imported or processed 25,000 pounds or more of any listed chemical had to report the nature and quantity of the chemical produced, imported, or processed. In 1987, approximately 20,000 enterprises reported their releases of such chemicals. A listing of the 329 selected chemicals is provided in Appendix B.

6

It should be understood that since different industries will emit a different number and composition of chemicals, each industry will have a different number of estimated chemical intensities. These

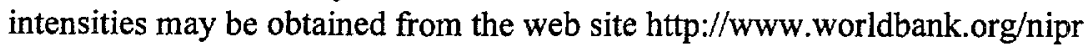


Figure 1

\section{Industrial Pollution Projection System \\ Pollution Intensity}

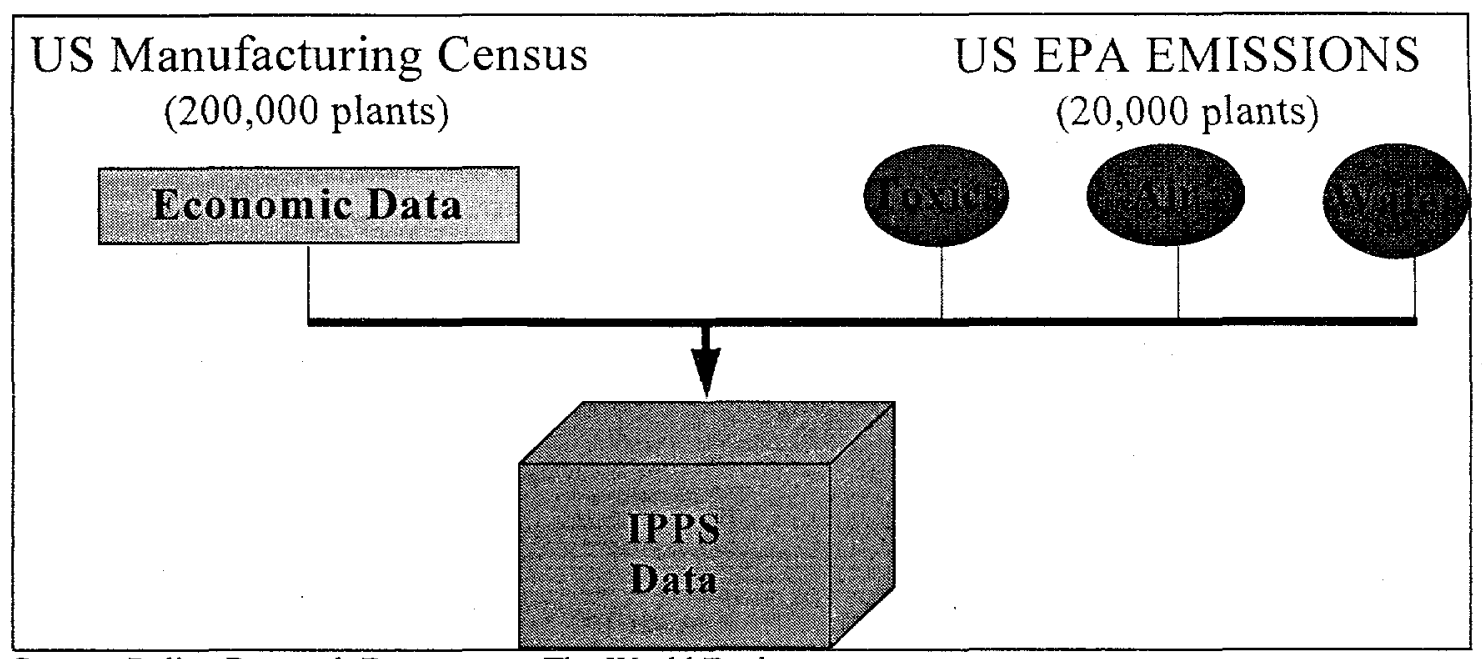

Source: Policy Research Department, The World Bank

For Brazil, we were able to obtain 1994 employment figures for every industrial sector, for all 3426 industrialized municipals. Multiplying these figures by the associated employment-based chemical intensity obtained from IPPS resulted in the total chemical load per industrial sector per municipal (or state). ${ }^{7}$ Summing across all industries in a state or municipal yielded the estimated releases of chemicals in the state or municipality. In what follows, these estimates, unweighted for toxicity risk, are referred to as the "volume" ranking (or $\mathrm{Q}_{\mathrm{ix}}$ in equation 2) since it is solely based on the total volume of releases, with no account of relative risk. These estimates can finally be weighted for

While absolute estimates of pollution emissions differ upon using employment-based pollution intensities and value-based pollution intensities, Hettige et al. (1995) and Laplante and Smits (1998) have shown that the ranking of industrial sectors (from largest polluters to smallest) remains the same. Moreover, Wheeler et al. (1998) in a comparative analysis of 12 countries, including Brazil, have found the ratio (Pollution emission / Employment) to be relatively constant across countries for the same industrial sectors. 
their relative toxicity as shown previously (multiplied by $w_{i j}$ ). Results are presented for each of the 10 indices shown in Table 2.

\section{(iii) Pollution load in Brazil}

We first begin at the aggregate level, looking at pollution emissions at the state level for the entire country. In Table 7, observe that São Paulo ranks first, perhaps unsurprisingly, in terms of pollution emissions, both weighted and unweighted. More importantly, observe that the risk weighted rankings of the states are relatively similar across indices. HBEL and TRI offer slightly different rankings which may be explained by the fact that these are the long-term exposure indices in our analysis. The volume ranking, while providing a different ranking than the risk weighted rankings also performs relatively well, especially for those states ranked as the largest and those ranked as the smallest producers of toxic emissions. Hence, despite a few notable exceptions, state level rankings remain, for the most part, consistent across the risk indicators and with the volume indicator. 
Table 7

Ranking of Brazilian states, indexed on TLV*

\begin{tabular}{|c|c|c|c|c|c|c|c|c|c|c|c|}
\hline State & $\mathrm{TLV}$ & PEL & REL & MAK & HBEL & TEEL-0 & TEEL-1 & TEEL-2 & TEEL-3 & TRI & Volume \\
\hline São Paulo & 1 & 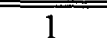 & 1 & 1 & $\bar{~} 1$ & $\overline{11}$ & 1 & 1 & 1 & 1 & 1 \\
\hline Paraná & 2 & 2 & 5 & 2 & 2 & $\overline{4}$ & 2 & 2 & 2 & 5 & 4 \\
\hline Minas Gerais & 3 & 4 & 2 & 4 & 6 & 2 & 4 & 4 & 3 & 4 & 2 \\
\hline Santa Catarina & 4 & 3 & 6 & 3 & 3 & 6 & 3 & 3 & 4 & 6 & 3 \\
\hline Rio Grande do Sul & 5 & 6 & 4 & 5 & 5 & 5 & 5 & 5 & 6 & 3 & 6 \\
\hline Pará & 6 & 5 & 7 & 6 & 4 & 7 & 7 & 6 & 7 & 8 & 10 \\
\hline Rio de Janeiro & 7 & 7 & 3 & 7 & 7 & 3 & 6 & 7 & 5 & 2 & 5 \\
\hline Ceará & 8 & 10 & 9 & 8 & 14 & 8 & 8 & 8 & 8 & 10 & 7 \\
\hline Bahia & 9 & 8 & 8 & 9 & 10 & 9 & 9 & 9 & 9 & 7 & 8 \\
\hline Mato Grosso do Sul & 10 & 9 & 13 & 10 & 8 & 12 & 11 & 10 & 11 & 11 & 17 \\
\hline Pernambuco & 11 & 12 & 10 & 11 & 15 & 10 & 10 & 11 & 10 & 9 & 9 \\
\hline Rondônia & 12 & 13 & 16 & 13 & 9 & 15 & 14 & 13 & 15 & 18 & 22 \\
\hline Espírito Santo & 13 & 11 & 11 & 12 & 12 & 11 & 13 & 12 & 12 & 13 & 12 \\
\hline Amazonas & 14 & 14 & 14 & 15 & 11 & 14 & 16 & 14 & 16 & 15 & 18 \\
\hline Maranhão & 15 & 15 & 17 & 17 & $\overline{13}$ & 17 & 17 & 15 & 17 & 14 & 21 \\
\hline Rio Grande do Norte & 16 & 17 & 15 & 14 & 18 & 16 & 12 & 16 & 13 & 17 & 11 \\
\hline Goiás & 17 & 16 & 12 & 16 & 17 & 13 & 15 & 17 & 14 & 12 & 13 \\
\hline Mato Grosso & 18 & 18 & 19 & 19 & 16 & 19 & 19 & 18 & 19 & 20 & 20 \\
\hline Alagoas & 19 & 19 & 18 & 18 & 21 & 18 & 18 & 19 & 18 & 19 & 16 \\
\hline Paraíba & 20 & 20 & 20 & 20 & 24 & 20 & 20 & 20 & 20 & 22 & 14 \\
\hline Piauí & 21 & 22 & 21 & 21 & 25 & 21 & 21 & 21 & 21 & 16 & 19 \\
\hline Distrito Federal & 22 & 21 & 22 & 23 & 20 & 22 & 23 & 23 & 23 & 21 & 23 \\
\hline Sergipe & 23 & 23 & 23 & 22 & 23 & 23 & 22 & 22 & 22 & 24 & 15 \\
\hline Acre & 24 & 24 & 24 & 24 & 19 & 24 & 24 & 24 & 24 & 25 & 24 \\
\hline Tocantins & 25 & 25 & 25 & 25 & 22 & 25 & 25 & 25 & 25 & 26 & 25 \\
\hline Amapá & 26 & 26 & 26 & 26 & 26 & 26 & 26 & 26 & 26 & 23 & 26 \\
\hline Roraima & 27 & 27 & 27 & 27 & 27 & 27 & 27 & 27 & 27 & 27 & 27 \\
\hline
\end{tabular}

* - TLVs have been in use since 1946 and are the basis of numerous other indices (such as PEL, REL and MAK). In addition, TLVs are continuously revised to account for recent scientific research. 
If we examine our estimates at a dis-aggregate (municipal) level for São Paulo and Rio, observe in Tables 8 and 9 that the rankings of municipals remain more or less identical across the risk-weighed indices, with the exceptions of HBEL and TRI for which the ranking of municipals vary the most with the other risk-weighted rankings. This is especially the case for São Paulo. Most striking however is the markedly different ranking obtained when risk is unweighted (volume ranking).

Table 8

Top 20 municipalities for Rio de Janeiro, indexed on TLV ${ }^{(1)}$

\begin{tabular}{|c|c|c|c|c|c|c|c|c|c|c|c||}
\hline $\begin{array}{c}\text { Municipal } \\
\text { code }\end{array}$ & TLV & PEL & REL & MAK & HBEL & TEEL-0 & TEEL-1 & TEEL-2 & TEEL-3 & TRI & Volume \\
\hline \hline 330455 & 1 & 1 & 1 & 1 & 1 & 1 & 1 & 1 & 1 & 1 & 1 \\
\hline 330630 & 2 & 2 & 2 & 2 & 2 & 2 & 2 & 2 & 3 & 2 & 11 \\
\hline 330170 & 3 & 3 & 3 & 3 & 3 & 5 & 3 & 3 & 2 & 3 & 2 \\
\hline 330350 & 4 & 4 & 4 & 4 & 6 & 7 & 4 & 4 & 4 & 4 & 8 \\
\hline 330340 & 5 & 6 & 5 & 7 & 11 & 9 & 8 & 6 & 7 & 8 & 4 \\
\hline 330040 & 6 & 5 & 6 & 6 & 4 & 6 & 5 & 5 & 8 & 9 & 14 \\
\hline 330330 & 7 & 10 & 8 & 5 & 5 & 3 & 6 & 8 & 9 & 6 & 6 \\
\hline 330490 & 8 & 7 & 7 & 8 & 7 & 8 & 7 & 7 & 5 & 7 & 9 \\
\hline 330010 & 9 & 31 & 14 & 9 & 8 & 4 & 11 & 20 & 24 & 15 & 17 \\
\hline 330390 & 10 & 9 & 10 & 10 & 9 & 11 & 9 & 9 & 10 & 10 & 3 \\
\hline 330025 & 11 & 12 & 11 & 11 & 16 & 14 & 10 & 10 & 6 & 5 & 16 \\
\hline 330510 & 12 & 13 & 9 & 13 & 19 & 15 & 16 & 15 & 14 & 12 & 15 \\
\hline 330030 & 13 & 11 & 13 & 12 & 10 & 10 & 14 & 11 & 15 & 13 & 22 \\
\hline 330200 & 14 & 18 & 17 & 15 & 17 & 12 & 17 & 12 & 20 & 16 & 26 \\
\hline 330580 & 15 & 15 & 15 & 17 & 15 & 20 & 19 & 16 & 19 & 20 & 10 \\
\hline 330100 & 16 & 14 & 18 & 14 & 14 & 16 & 12 & 14 & 11 & 11 & 19 \\
\hline 330240 & 17 & 19 & 20 & 19 & 20 & 17 & 21 & 18 & 22 & 19 & 30 \\
\hline 330250 & 18 & 17 & 19 & 16 & 18 & 19 & 13 & 17 & 16 & 23 & 13 \\
\hline 330080 & 19 & 21 & 31 & 22 & 12 & 29 & 24 & 23 & 29 & 27 & 39 \\
\hline 330190 & 20 & 16 & 16 & 24 & 23 & 21 & 22 & 19 & 13 & 21 & 25 \\
\hline \hline
\end{tabular}

(1) - Total number of industrialized municipals is 75 . 
Table 9

Top 20 municipalities for São Paulo, indexed on TLV ${ }^{(1)}$

\begin{tabular}{|c|c|c|c|c|c|c|c|c|c|c|c|}
\hline $\begin{array}{c}\text { Municipal } \\
\text { code }\end{array}$ & TLV & PEL & REL & MAK & HBEL & TEEL-0 & TEEL-1 & TEEL-2 & TEEL-3 & TRI & Volume \\
\hline \hline 355030 & 1 & 1 & 1 & 1 & 1 & 1 & 1 & 1 & 1 & 1 & 1 \\
\hline 354870 & 2 & 2 & 2 & 2 & 2 & 2 & 2 & 2 & 2 & 3 & 3 \\
\hline 354840 & 3 & 4 & 3 & 4 & 40 & 9 & 7 & 4 & 8 & 11 & 23 \\
\hline 351880 & 4 & 3 & 4 & 3 & 4 & 4 & 3 & 3 & 3 & 2 & 4 \\
\hline 354780 & 5 & 5 & 5 & 5 & 10 & 5 & 5 & 5 & 4 & 4 & 14 \\
\hline 351380 & 6 & 6 & 6 & 6 & 6 & 4 & 6 & 6 & 6 & 5 & 6 \\
\hline 350950 & 7 & 7 & 9 & 7 & 12 & 7 & 4 & 7 & 7 & 8 & 5 \\
\hline 351350 & 8 & 9 & 12 & 8 & 8 & 6 & 8 & 8 & 5 & 9 & 26 \\
\hline 353800 & 9 & 13 & 7 & 18 & 31 & 15 & 26 & 15 & 25 & 31 & 66 \\
\hline 354520 & 10 & 8 & 30 & 9 & 4 & 19 & 9 & 9 & 14 & 22 & 29 \\
\hline 352590 & 11 & 11 & 16 & 10 & 7 & 13 & 10 & 10 & 11 & 14 & 10 \\
\hline 355220 & 12 & 10 & 11 & 13 & 13 & 11 & 15 & 11 & 16 & 16 & 8 \\
\hline 353070 & 13 & 17 & 14 & 11 & 18 & 24 & 11 & 16 & 17 & 45 & 19 \\
\hline 352310 & 14 & 15 & 8 & 23 & 53 & 22 & 28 & 25 & 24 & 32 & 33 \\
\hline 353870 & 15 & 12 & 13 & 15 & 11 & 12 & 16 & 13 & 19 & 19 & 21 \\
\hline 350570 & 16 & 16 & 10 & 14 & 19 & 16 & 12 & 14 & 12 & 7 & 16 \\
\hline 355250 & 17 & 14 & 38 & 12 & 5 & 27 & 13 & 12 & 15 & 27 & 11 \\
\hline 354880 & 18 & 18 & 17 & 16 & 14 & 8 & 21 & 20 & 22 & 10 & 34 \\
\hline 351300 & 19 & 23 & 15 & 29 & 41 & 31 & 31 & 28 & 29 & 28 & 50 \\
\hline 353060 & 20 & 22 & 22 & 22 & 20 & 20 & 23 & 23 & 20 & 17 & 30 \\
\hline
\end{tabular}

(1) - Total number of industrialized municipals is 548 .

These results are confirmed upon calculating the Spearman rank correlation coefficient between each index. This coefficient, noted $r_{s}$, is calculated as follows:

$$
r_{s}=1-\frac{6 \sum_{i=1}^{n}\left(R_{i}-R_{j}\right)^{2}}{n\left(n^{2}-1\right)}
$$

where $R_{i}$ and $R_{j}$ is the rank of the municipal under methodology $i$ and $j$, and $n$ is the number of pairs of ranks ( $\mathrm{n}=75$ for Rio and 548 for São Paulo). Observe in Tables 10 and 11 that the rank correlation coefficients are significantly lower for the volume-based index, and higher across the risk-weighted indices with the exception of the long-term exposure HBEL and TRI indices. 
Table 10

Rank correlation coefficients for Rio de Janeiro

\begin{tabular}{|c|c|c|c|c|c|c|c|c|c|c|c|}
\hline & TLV & PEL & REL & MAK & HBEL & TEEL-0 & TEEL-1 & TEEL-2 & TEEL-3 & TRI & VOL \\
\hline TLV & 1.0000 & & & & & & & & & & \\
\hline PEL & 0.9586 & 1.0000 & & & & & & & & & \\
\hline REL & 0.9695 & 0.9839 & 1.0000 & & & & & & & & \\
\hline MAK & 0.9916 & 0.9630 & 0.9706 & 1.0000 & & & & & & & \\
\hline HBEL & 0.9759 & 0.9687 & 0.9619 & 0.9691 & 1.0000 & & & & & & \\
\hline TEEL-0 & 0.9800 & 0.9630 & 0.9809 & 0.9870 & 0.9617 & 1.0000 & & & & & \\
\hline TEEL-1 & 0.9822 & 0.9619 & 0.9688 & 0.9940 & 0.9557 & 0.9878 & 1.0000 & & & & \\
\hline TEEL-2 & 0.9864 & 0.9818 & 0.9830 & 0.9879 & 0.9747 & 0.9884 & 0.9871 & 1.0000 & & & \\
\hline TEEL-3 & 0.9744 & 0.9725 & 0.9757 & 0.9838 & 0.9492 & 0.9815 & 0.9880 & 0.9881 & 1.0000 & & \\
\hline TRI & 0.9613 & 0.9451 & 0.9609 & 0.9648 & 0.9390 & 0.9627 & 0.9621 & 0.9565 & 0.9602 & 1.0000 & \\
\hline VOL & 0.9368 & 0.8991 & 0.9209 & 0.9512 & 0.8944 & 0.9452 & 0.9514 & 0.9376 & 0.9570 & 0.9239 & 1.0000 \\
\hline
\end{tabular}

Table 11

Rank correlation coefficients for São Paulo

\begin{tabular}{|c|c|c|c|c|c|c|c|c|c|c|c|}
\hline & TLV & PEL & REL & MAK & HBEL & TEEL-0 & TEEL-1 & TEEL-2 & TEEL-3 & TRI & VOL \\
\hline TLV & 1.0000 & & & & & & & & & & \\
\hline PEL & 0.9704 & 1.0000 & & & & & & & & & \\
\hline REL & 0.9684 & 0.9818 & 1.0000 & & & & & & & & \\
\hline MAK & 0.9941 & 0.9751 & 0.9704 & 1.0000 & & & & & & & \\
\hline HBEL & 0.9560 & 0.9671 & 0.9351 & 0.9543 & 1.0000 & & & & & & \\
\hline TEEL-0 & 0.9791 & 0.9795 & 0.9812 & 0.9864 & 0.9524 & 1.0000 & & & & & \\
\hline TEEL-1 & 0.9849 & 0.9729 & 0.9687 & 0.9966 & 0.9459 & 0.9858 & 1.0000 & & & & \\
\hline TEEL-2 & 0.9849 & 0.9904 & 0.9765 & 0.9921 & 0.9654 & 0.9873 & 0.9911 & 1.0000 & & & \\
\hline TEEL-3 & 0.9693 & 0.9775 & 0.9712 & 0.9834 & 0.9352 & 0.9802 & 0.9874 & 0.9897 & 1.0000 & & \\
\hline TRI & 0.9596 & 0.9512 & 0.9585 & 0.9606 & 0.9427 & 0.9661 & 0.9570 & 0.9566 & 0.9510 & 1.0000 & \\
\hline VOL & 0.9373 & 0.9172 & 0.9349 & 0.9529 & 0.8827 & 0.9518 & 0.9594 & 0.9429 & 0.9540 & 0.9300 & 1.0000 \\
\hline
\end{tabular}


Figures 2 and 3 compare the TLV and volume rankings of all municipals of Rio (Figure 2) and São Paulo (Figure 3). In these figures, a darker shading is to be interpreted as more pollution intensive. ${ }^{8}$ Note in both figures that where the volume ranking would indicate a number of municipals as high priority (dark shade), the TLV index ranks a large number of these same municipal quite low, implying that the pollution loads are relatively non-toxic. These results indicate first that accounting for risk does make a significant difference in terms of identifying the areas (or industrial sectors) that should be deserving attention. They also indicate that in both São Paulo and Rio, a significant reduction of emissions of toxic chemicals could be obtained by allocating monitoring and control resources in a relatively small number or municipals.

Another noticeable result across the risk-weighted indices is between the short term (TEEL) and long term indices (HBEL and TRI). Note the lower correlation coefficients in Tables 10 and 11. In comparing the HBEL ranking with the short term lethal exposure index TEEL-3 in Figures 4 and 5, we observe a number of areas which have a larger potential to be lethal in the long term (i.e. Municipal code 330010; ranked $8^{\text {th }}$ by HBEL, $24^{\text {th }}$ by TEEL-3). Thus at greater levels of dis-aggregation, it appears that the outlook of risk (short or long term) becomes increasingly significant.

8 Graphs were constructed using ArcView 3.0 Geographical Information System. Estimates were divided into 7 shaded categories to highlight changes in relative ranking. For comparative purposes, the "volume" legend in Figures 2 and 3 were adjusted to match that of the TLV scale. 
Figure 2: Volume vs. TLV risk-weighted ranking of municipals for the Rio de Janeiro region

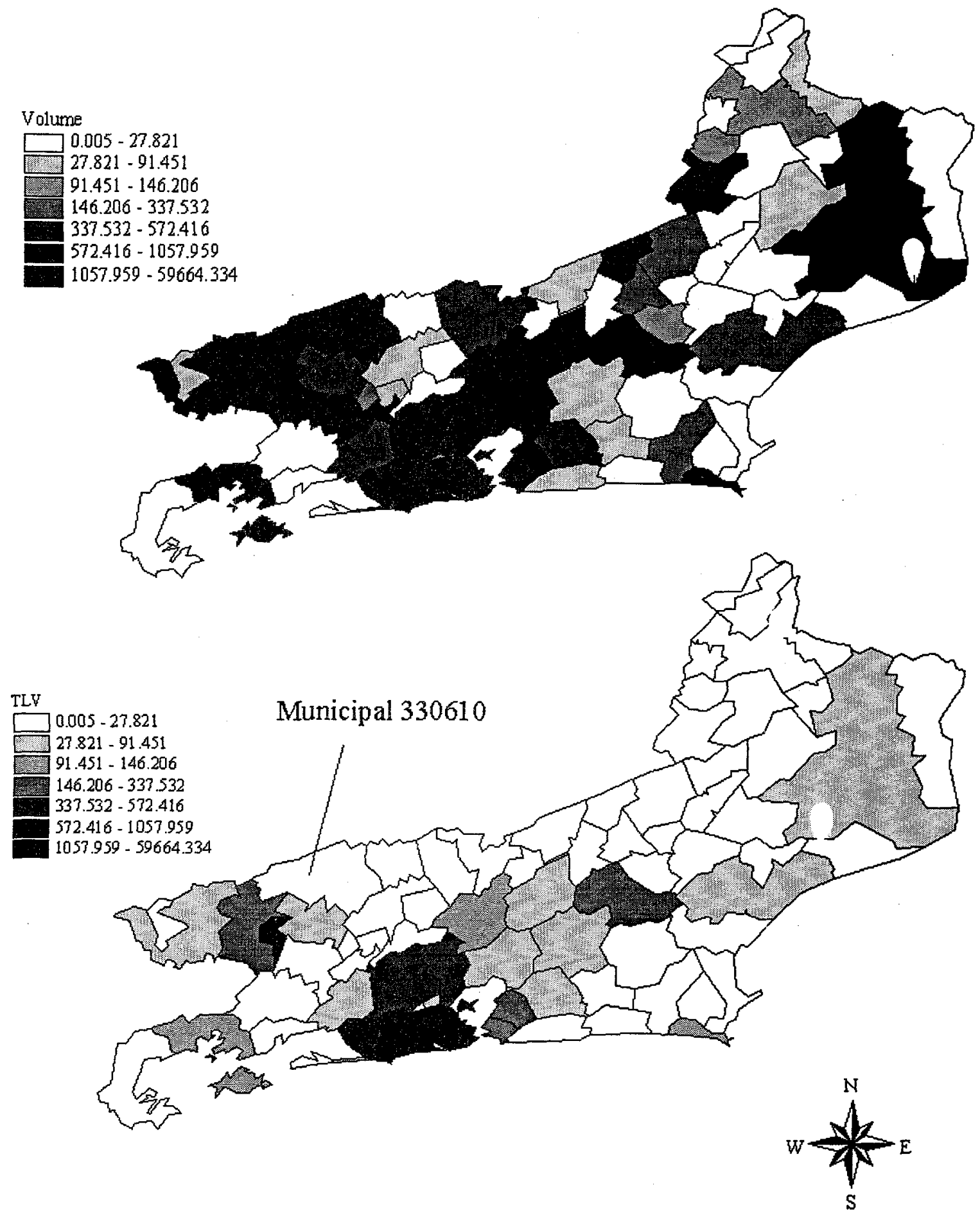


Figure 3: Volume vs. TLV risk-weighted ranking of municipals for the Sao Paulo region

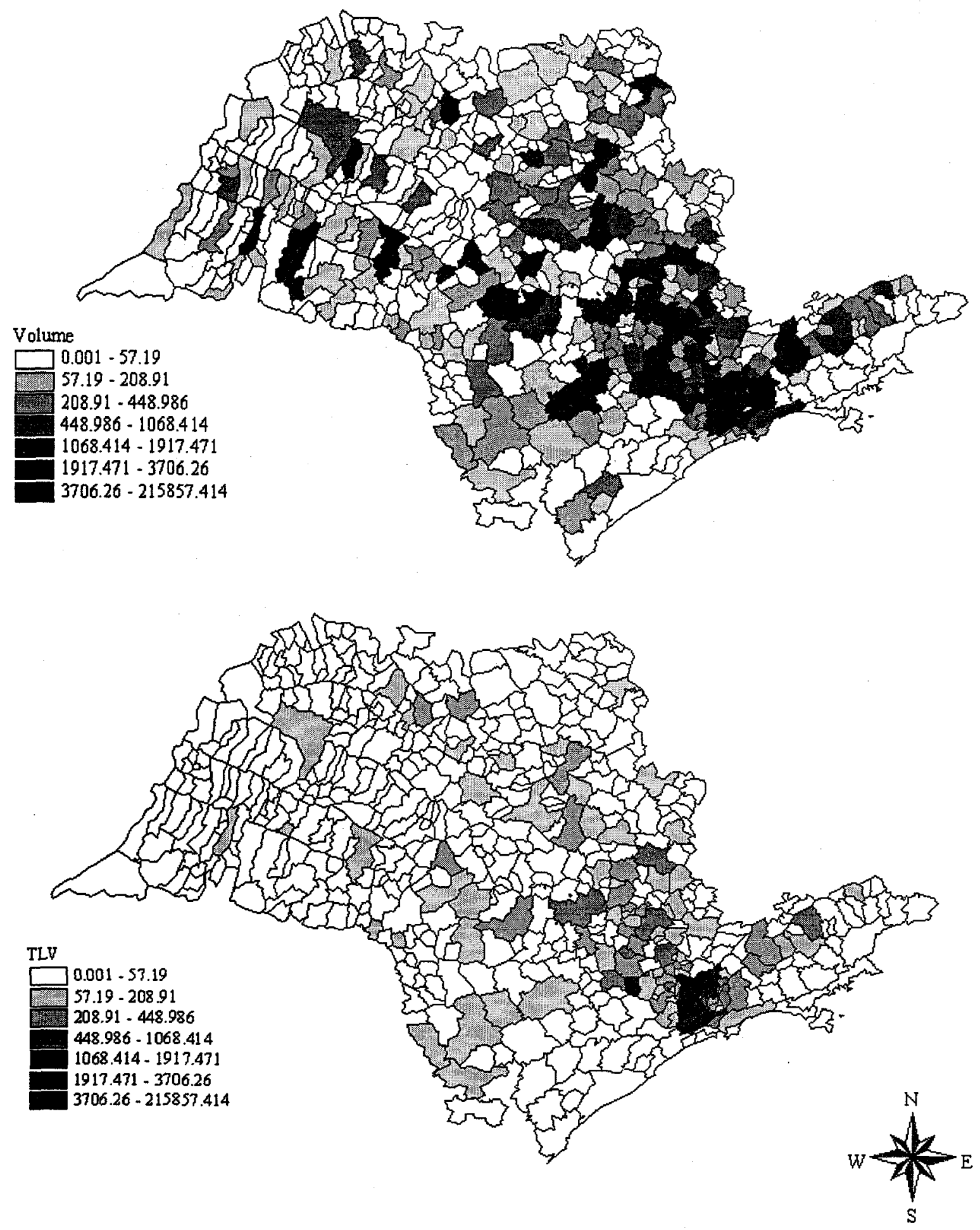


Figure 4: Acute (TEEL-3) vs. chronic-weighted (HBEL) ranking of municipals for the Rio de Janeiro region

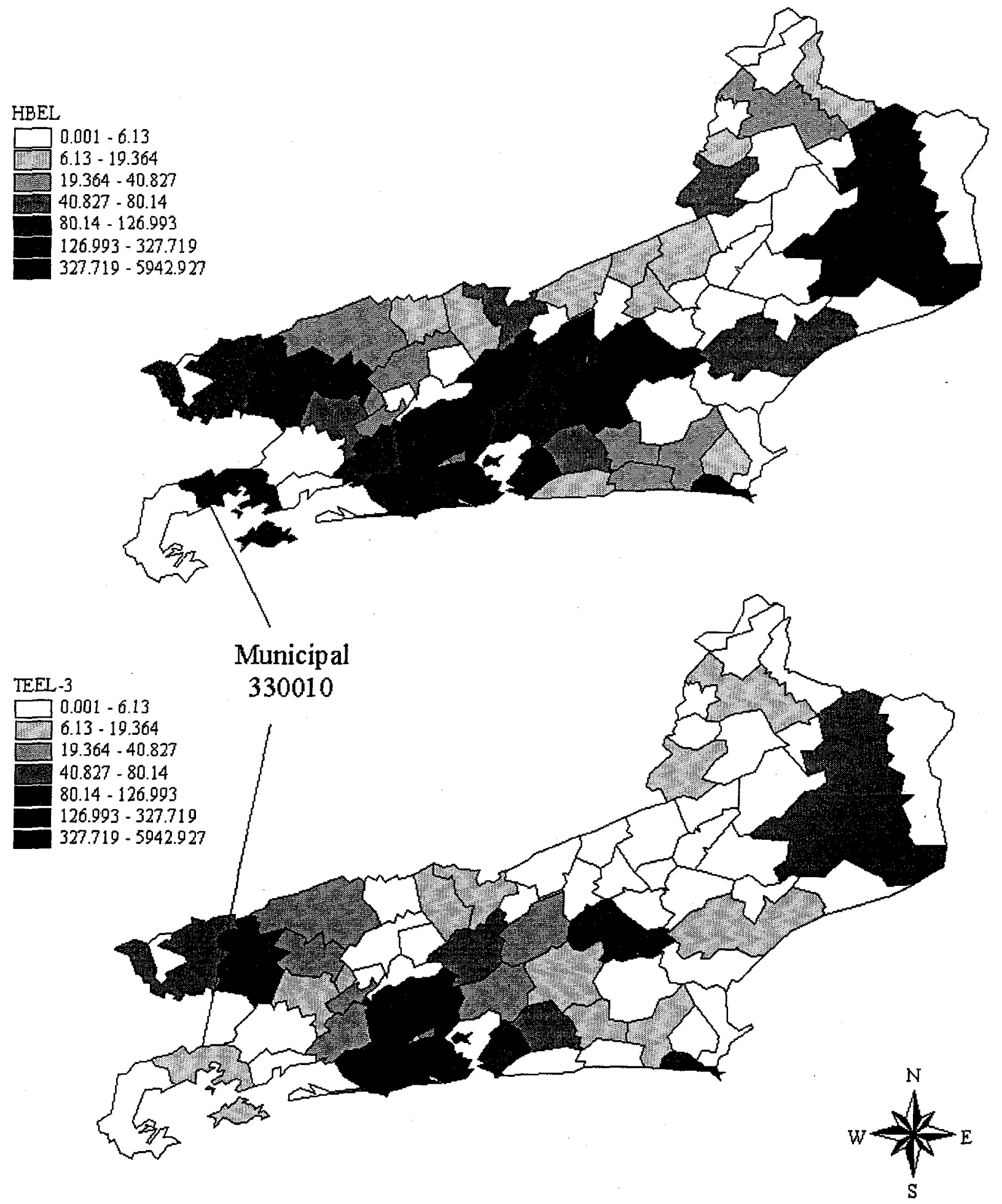


Figure 5: Acute (TEEL-3) vs. chronic-weighted (HBEL) ranking of municipals for the Sao Paulo region

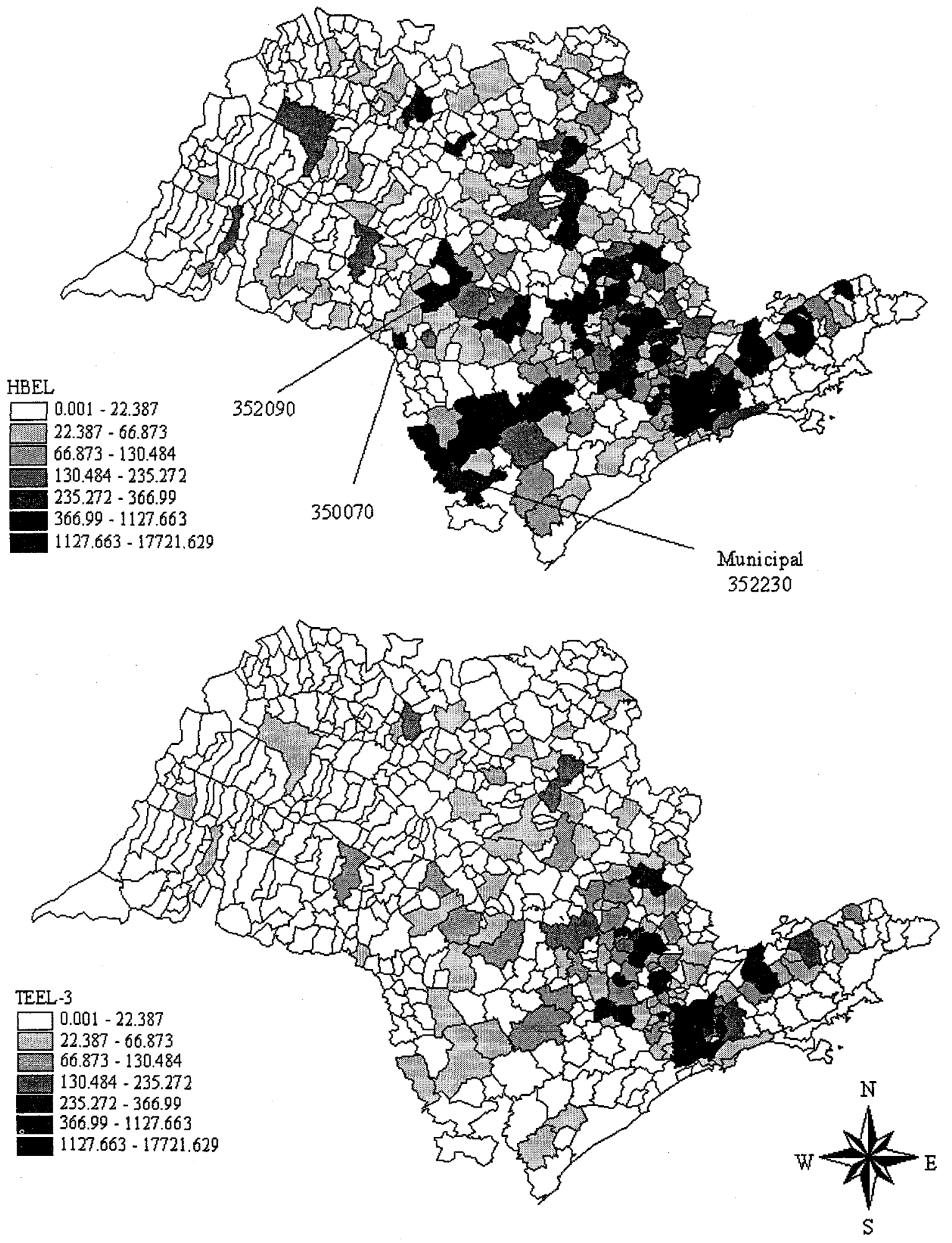




\section{Conclusion}

The accounting and public release of information pertaining to industrial toxic pollution emissions is meeting increasing criticism in that these listings typically do not account for the different toxicity risks associated with different pollutants: A firm emitting a large quantity of a relatively harmless substance would rank as a larger polluter than another firm emitting a small quantity of a very potent substance. It is argued that such "unweighted" rankings of firms may lead to a misallocation of resources and wrong prioritization of effort devoted to pollution control. This may be of particular importance for developing countries where resources devoted to pollution control are typically scarce.

In an attempt to account for the relative differences in chemical toxicity, a number of organizations have developed thresholds or exposure limits for various pollutants to account for their various toxicity risk. Given the large number of toxicity risk factors and methodologies currently available, a crucial issue pertains to the possibility that different risk indicators may yield different results, thus leading to different sets of priorities. In this paper, we have reviewed and applied to Brazil seven risk methodologies currently available, and constructed 10 different sets of toxicity risk factors from these indicators. Upon ranking states and municipals for their pollution intensity, results indicate that at the state level, risk weighted rankings remain largely the same across the 10 different sets of toxicity risk factors used in this paper. This result by and large also holds true at the 
municipal level with the exception of the long-term exposure indices (HBEL and TRI) which offer different rankings of pollution intensive municipals. Moreover, at the state level, the unweighted ranking is relatively similar to the risk weighted ranking. However, at the municipal level, significant differences were found between the risk weighted and unweighted rankings.

These findings suggest that it is of importance for environmental regulators to engage into weighting pollutants for their relative toxicity risk when prioritizing pollution control effort either at the industrial or regional level. This exercise appears to be of greater importance as one seeks to determine prioritization of pollution control effort at a greater level of dis-aggregation. 


\section{References}

American Conference of Governmental Industrial Hygienists (1997), Guide to Occupational Exposure Values - 1997, Cincinnati, ACGIH.

Hamilton, J.T. (1995), "Pollution as News: Media and Stock Market Reactions to the Toxic Release Inventory Data", Journal of Environmental Economics and Management, 28: 98-113.

Health Based Exposure Limits Committee (1995), Chemical Exposure Guidelines, Santa Clara Center for Occupational Safety and Health (SCCOSH) at http://turva.me.tut.fi/cgi-bin/wilma/chesa.840022811.html (obtained November 1997).

Hettige, M., D. Wheeler, (1996), An Environmental Performance Analysis System for Industrial Plants in Mexico, mimeo, Development Research Group, The World Bank, Washington, D.C.

Hettige, M., P. Martin, M. Singh and D. Wheeler (1995), The Industrial Pollution Projection System, Working Paper Series, No. 1431, Development Research Group, The World Bank, Washington, D.C.

Hettige, H., Mani, M. and D. Wheeler (1998), Industrial Pollution in Economic Development (Kuznets Revisited), Working Paper Series, No. 1876, Development Research Group, The World Bank, Washington, D.C.

Horvath, A., C. T. Hendrickson, L. B. Lave, F. C. McMichael and T-S. Wu (1995), "Toxic Emissions Indices for Green Design and Inventory", Environmental Science \& Technology, 29, 2: 86A-90A.

Instituto Brasileiro de Geografia e Estatísticsa (IBGE), Anuário Estatístico do Brasil, 1995.

IBGE, Directoria de Geociências, Departamento de Estudos Territoriais, 1995 at http://www.ibge.org/english/brasil/other6.html (obtained June 1, 1998).

Instituto de Pesquisa Económica Aplicada (IPEA), Boletim Conjuntural, 1994.

Konar, S. and M. A. Cohen (1997), "Information as Regulation: The Effect of Community Right-to-Know Laws on Toxic Emissions", Journal of Environmental Economics and Management, 32, 1: 109-124.

Laplante, B. and K. Smits (1998), Industrial Pollution in Latvia, mimeo, Development Research Group, The World Bank, Washington, D.C. 
Lewis, R. J., Sr. (Ed.) (1997), Sax's Dangerous Properties of Industrial Materials, $9^{\text {th }}$ Ed. Van Nostrand Reinhold, New York, August.

NIOSH Pocket Guide to Chemical Hazards (1994), U.S. Department of Health and Human Services, Public Health Service, Centers for Disease Control, June.

Swanson, M., G. A. Davis, L. E. Kincaid, T. W. Schultz, J. E. Bartmess, S.L. Jones and E. L. George (1997), "A Screening Method for Ranking and Scoring Chemicals by Potential Human Health and Environmental Impacts", Environmental Toxicology and Chemistry, 16, 2: 372-383.

"Temporary Emergency Exposure Limits" (1998), U.S. Department of Energy, Subcommittee on Consequence Assessment and Protective Action (SCAPA), Rev.13,WSMS-SAE-98-0001at

http://dewey.tis.eh.doe.gov/web/chem safety/doe reg.html (obtained February, 1998).

"Toxic Release Inventory Indicators Toxicity Weights" (1998), U.S. Environmental Protection Agency, Office of Pollution Prevention and Toxics, Sector Facility Indexing Project, Washington, D.C. at http://es.epa.gov/oeca/sfi/sabrev.html (obtained January, 1998).

World Bank (1996), Brazil, Managing Environmental Pollution in the State of Rio de Janeiro, Vol. I \& II, Report No. 15488-BR.

World Bank (1998), Brazil, Managing Environmental Pollution Problems: The Brown Environmental Agenda, Vol. I: Policy Report, No. 16635-BR. 


\section{Appendix A \\ Further details of risk indicators}

TCLo - Toxic Concentration Low - the lowest concentration of a substance in air to which humans or animals have been exposed for any given period of time that has produced any toxic effect in humans or produced a carcinogenic, neoplastigenic, or teratogenic effect in animals or humans.

TDLo - Toxic Dose Low - the lowest dose of a substance introduced by any route, other than inhalation, over any given period of time and reported to produce any toxic effect in humans or to produce carcinogenic, neoplastigenic, or teratogenic effects in animals or humans.

LCLo - Lethal Concentration Low - the lowest concentration of a substance in air, other than LC50, which has been reported to have caused death in humans or animals. The reported concentrations may be entered for periods of exposure which are less than 24 hours (acute) or greater than 24 hours (subacute and chronic).

LDLo - Lethal Dose Low - the lowest dose (other than LD50) of a substance introduced by any route, other than inhalation, over any given period of time in one or more divided portions and reported to have caused death in humans or animals.

LD50 - Lethal Dose Fifty - a calculated dose of a substance which is expected to cause the death of $50 \%$ of an entire defined experimental animal population. It is determined from the exposure to the substance by any route other than inhalation of a significant number from that population. 


\section{Appendix B \\ Chemical substances in analysis}

\begin{tabular}{|c|c|}
\hline CAS & Substance \\
\hline 71556 & 1,1,1-TRICHLOROETHANE (METHYL CHLOROFORM) \\
\hline 79345 & 1,1,2,2-TETRACHLOROETHANE \\
\hline 76131 & 1,1,2-TRICHLORO-1,2,2-TRIFLUOROETHANE (FREON 113) \\
\hline 79005 & 1,1,2-TRICHLOROETHANE \\
\hline 57147 & 1,1-DIMETHYL HYDRAZINE \\
\hline 120821 & 1,2,4-TRICHLOROBENZENE \\
\hline 95636 & 1,2,4-TRIMETHYLBENZENE (PSEUDOCUMENE) \\
\hline 106887 & 1,2-BUTYLENE OXIDE (1,2-EPOXYBUTANE) \\
\hline 96128 & 1,2-DIBROMO-3-CHLOROPROPANE (DBCP) \\
\hline 106934 & 1,2-DIBROMOETHANE (EDB) (ETHYLENE DIBROMIDE) \\
\hline 107062 & 1,2-DICHLOROETHANE (ETHYLENE DICHLORIDE) \\
\hline 540590 & 1,2-DICHLOROETHYLENE \\
\hline 78875 & 1,2-DICHLOROPROPANE (PROPYLENE DICHLORIDE) \\
\hline 122667 & 1,2-DIPHENYLHYDRAZINE (HYDRAZOBENZENE) \\
\hline 106990 & 1,3-BUT ADIENE \\
\hline 541731 & 1,3-DICHLOROBENZENE (M-ISOMER) \\
\hline 542756 & 1,3-DICHLOROPROPYLENE \\
\hline 123911 & 1,4-DIOXANE (1,4-DIETHYLENE DIOXIDE) \\
\hline 82280 & 1-AMMNO-2-METHYLANTHRAQUINONE \\
\hline 95954 & 2,4,5-TRICHLOROPHENOL \\
\hline 88062 & 2,4,6-TRICHLOROPHENOL \\
\hline 94757 & 2,4-D (DICHLOROPHENOXYACETIC ACID) \\
\hline 39156417 & 2,4-DIAMINO ANISOLE SULFATE \\
\hline 615054 & 2,4-DIAMINOSANISOLE \\
\hline 95807 & 2,4-DIAMINOTOLUENE \\
\hline 120832 & 2,4-DICHLOROPHENOL \\
\hline 105679 & 2,4-DIMETHYLPHENOL \\
\hline 51285 & 2,4-DINITROPHENOL \\
\hline 121142 & 2,4-DINITROTOLUENE \\
\hline 606202 & 2,6-DINITROTOLUENE \\
\hline 87627 & 2,6-XYLIDINE \\
\hline 53963 & 2-ACETOAMINOFLUORENE \\
\hline 117793 & 2-AMINOANTHRAQUINONE \\
\hline 532274 & 2-CHLOROACETOPHENONE (ALPHA) (PHENACYL CHORIDE) \\
\hline 110805 & 2-ETHOXYETHANOL (ETHYLENE GLYCOL MONOETHYL ETHER; CELLOSOLVE) \\
\hline 109864 & $\begin{array}{l}\text { 2-METHOXYETHANOL (ETHYLENE GLYCOL MONOMETHYL ETHER; METHYL } \\
\text { CELLOSOLVE) }\end{array}$ \\
\hline 88755 & 2-NITROPHENOL \\
\hline 79469 & 2-NITROPROPANE \\
\hline 90437 & 2-PHENYLPHENOL (SODIUM SALT) \\
\hline 91941 & 3,3'-DICHLOROBENZIDINE (AZO DYE) \\
\hline 119904 & 3,3'-DIMETHOXYBENZIDINE (AZO DYE; o-DIANISIDINE) \\
\hline 119937 & 3,3'-DIMETHYLBENZIDINE (AZO DYE; o-TOLIDINE) \\
\hline 101804 & 4,4'-DIAMINODIPHENYL ETHER (4,4'-OXYDIANILINE) \\
\hline 80057 & 4,4'-ISOPROPYLIDENEDIPHENOL (BISPHENOL A) \\
\hline 101144 & 4,4'-METHYLENE BIS(2-CHLOROANILINE) (MBOCA) \\
\hline 101611 & 4,4'-METHYLENE BIS(N,N-DIMETHYL) BENZELAMINE \\
\hline 101779 & 4,4'-METHYLENE DIANILINE (4,4'-DIAMINODIPHENYLMETHANE) \\
\hline 139651 & 4,4'-THIODIANILINE \\
\hline 534521 & 4,6-DINITRO-O-CRESOL \\
\hline 60093 & 4-AMINOAZOBENZENE \\
\hline
\end{tabular}




\begin{tabular}{|c|c|}
\hline $\mathbf{C A S}$ & Substance \\
\hline 92671 & 4-AMINODIPHENYL (P-isomer) \\
\hline 60117 & 4-DIMETHYLAMINOAZOBENZENE \\
\hline 92933 & 4-NITRODIPHENYL (P-isomer) \\
\hline 100027 & 4-NITROPHENOL \\
\hline 99592 & 5-NITRO-O-ANISIDINE \\
\hline 75070 & ACETALDEHYDE \\
\hline 60355 & ACETAMIDE \\
\hline 67641 & ACETONE \\
\hline 75058 & ACETONITRILE \\
\hline 107028 & ACROLEIN \\
\hline 79061 & ACRYLAMIDE \\
\hline 79107 & ACRYLIC ACID \\
\hline $10713 !$ & ACRYLONITRILE (VINYL CYANIDE) \\
\hline 309002 & ALDRIN (1,4,5,8-DIMETHANONAPHTHALENE) \\
\hline 107051 & ALLYL CHLORIDE \\
\hline 7429905 & ALUMINUM (FUME OR DUST) \\
\hline 1344281 & ALUMINUM OXIDE (FIBROUS FORM) \\
\hline 97563 & AMINOAZOTOLUENE, O-ISOMER (C.I. SOLVENT YELLOW 3) \\
\hline 7664417 & AMMONIA \\
\hline 6484522 & AMMONIUM NITRATE (SOLUTION) \\
\hline 7783202 & AMMONIUM SULFATE (SOLUTION) \\
\hline 62533 & ANILINE \\
\hline 90040 & ANISIDINE (O-ISOMER) \\
\hline 104949 & ANISIDINE (P-ISOMER) \\
\hline 134292 & ANISIDINE HYDROCHLORIDE (O-ISOMER) \\
\hline 120127 & ANTHRACENE \\
\hline 7440360 & ANTIMONY \\
\hline 7440382 & ARSENIC \\
\hline 1332214 & ASBESTOS (FRIABLE) \\
\hline 492808 & AURAMINE (C.I. SOLVENT YELLOW 34) \\
\hline 7440393 & BARIUM \\
\hline 98873 & BENZAL CHLORIDE \\
\hline 55210 & BENZAMIDE \\
\hline 71432 & BENZENE \\
\hline 92875 & BENZIDINE \\
\hline 98077 & BENZOIC TRICHLORIDE (BENZYL TRICHLORIDE; TRICHLOROMETHYLBENZENE) \\
\hline 98884 & BENZOYL CHLORIDE \\
\hline 94360 & BENZOYL PEROXIDE \\
\hline 100447 & BENZYL CHLORIDE \\
\hline 7440417 & BERYLLIUM \\
\hline 92524 & BIPHENYL (DIPHENYL) \\
\hline 108601 & BIS(2-CHLORO-1-METHYLETHYL) ETHER (DICHLOROISOPROPYL ETHER) \\
\hline 111444 & BIS(2-CHLOROETHYL) ETHER (DICHLOROETHYL ETHER; 2,2'-DICHLORODIETHYL ETHER) \\
\hline 103231 & BIS(2-ETHYLHEXYL) ADIPATE \\
\hline 542881 & BIS(CHLOROMETHYL) ETHER (DICHLOROMETHYL ETHER) (BCME) \\
\hline 75252 & BROMOFORM (TRIBROMOMETHANE) \\
\hline 141322 & BUTYL ACRYLATE (ACRYLIC ACID \& N-BUYTL ESTER) \\
\hline 78922 & BUTYL ALCOHOL (SEC-BUTANOL) \\
\hline 75650 & BUTYL ALCOHOL (TERT-BUTANOL) \\
\hline 85687 & BUTYL BENZYL PHTHALATE \\
\hline 123728 & BUTYRALDEHYDE \\
\hline 2650182 & C.I. ACID BLUE 9, DIAMMONIUM SALT \\
\hline 3844459 & C.I. ACID BLUE 9, DISODIUM SALT \\
\hline 4680788 & C.I. ACID GREEN 3 \\
\hline
\end{tabular}




\begin{tabular}{|c|c|}
\hline CAS & Substance \\
\hline 569642 & C.I. BASIC GREEN 4 \\
\hline 989388 & C.I. BASIC RED 1 \\
\hline 1937377 & C.I. DIRECT BLACK 38 \\
\hline 2602462 & C.I. DIRECT BLUE 6 \\
\hline 16071866 & C.I. DIRECT BROWN 95 \\
\hline 2832408 & C.I. DISPERSE YELLOW 3 \\
\hline 81889 & C.I. FOOD RED 15 \\
\hline 3761533 & C.I. FOOD RED 5 \\
\hline 3118976 & C.I. SOLVENT ORANGE 7 \\
\hline 842079 & C.I. SOLVENT YELLOW 14 \\
\hline 128665 & C.I. VAT YELLOW 4 \\
\hline 7440439 & CADMIUM \\
\hline 156627 & CALCIUM CYANAMIDE \\
\hline 133062 & CAPTAN \\
\hline 63252 & CARBARYL (SEVIN) \\
\hline 75150 & CARBON DISULFIDE \\
\hline 56235 & CARBON TETRACHLORIDE (TETRACHLOROMETHANE) \\
\hline 463581 & CARBONYL SULFIDE \\
\hline 120809 & CATECHOL (PYROCATECHOL) \\
\hline 133904 & CHLORAMBEN (3-AMINO-2,5-DICHLOROBENZOIC ACID) \\
\hline 57749 & CHLORDANE \\
\hline 7782505 & CHLORINE \\
\hline 10049044 & CHLORINE DIOXIDE \\
\hline 79118 & CHLOROACETIC ACID \\
\hline 108907 & CHLOROBENZENE (CHLORINATED BENZENE) \\
\hline 510156 & CHLOROBENZILATE (4,4'-DICHLORO-BENZILIC ACID ETHYL ESTER) \\
\hline 67663 & CHLOROFORM \\
\hline 107302 & CHLOROMETHYL METHYL ETHER (CMME) \\
\hline 126998 & CHLOROPRENE (BETA-CHLOROPRENE; NEOPRENE) \\
\hline 1897456 & CHLOROTHALONIL \\
\hline 7440473 & CHROMIUM \\
\hline 7440484 & COBALT \\
\hline 7440508 & COPPER (FUME OR DUST) \\
\hline 120718 & CRESIDINE (P-ISOMER) \\
\hline 1319773 & CRESOL (ALL ISOMERS) \\
\hline 108394 & CRESOL (M-ISOMER) \\
\hline 95487 & CRESOL (O-ISOMER) \\
\hline 106445 & CRESOL (P-ISOMER) \\
\hline 98828 & CUMENE \\
\hline 80159 & CUMENE HYDROPEROXIDE \\
\hline 135206 & CUPFERRON \\
\hline 110827 & CYCLOHEXANE \\
\hline 1163195 & DECABROMODIPHENYL OXIDE \\
\hline 117817 & DI (2-ETHYLHEXYL) OR (SEC-OCTYL) PHTHALATE (DEHP) \\
\hline 2303164 & DIALLATE \\
\hline 25376458 & DIAMINOTOLUENE (MIXED ISOMERS) \\
\hline 334883 & DIAZOMETHANE \\
\hline 132649 & DIBENZOFURAN \\
\hline$\overline{84742}$ & DIBUTYL PHTHALATE \\
\hline 25321226 & DICHLOROBENZENE (MIXED ISOMERS) \\
\hline 95501 & DICHLOROBENZENE 1,2-(O-ISOMER) \\
\hline 106467 & DICHLOROBENZENE 1,4-(P-ISOMER) \\
\hline 75274 & DICHLOROBROMOMETHANE (BROMOCHLORO.) \\
\hline 75092 & DICHLOROMETHANE (METHYLENE CHLORIDE) \\
\hline
\end{tabular}




\begin{tabular}{|c|c|}
\hline CAS & Substance \\
\hline 62737 & DICHLORVOS \\
\hline 115322 & DICOFOL \\
\hline 1464535 & DIEPOXYBUTANE \\
\hline 111422 & DIETHANOLAMINE \\
\hline 84662 & DIETHYL PHTHALATE \\
\hline 64675 & DIETHYL SULFATE \\
\hline 131113 & DIMETHYL PHTHALATE \\
\hline 77781 & DIMETHYL SULFATE \\
\hline 121697 & DIMETHYLANILINE (N,N-DIMETHYLANILINE) \\
\hline 79447 & DIMETHYLCARBAMOYL CHLORIDE \\
\hline 117840 & DI-N-OCTYL PHTHALATE \\
\hline 106898 & EPICHLOROHYDRIN (1-CHLORO-2,3-EPOXYPROPANE) \\
\hline 140885 & ETHYL ACRYLATE (ACRYLIC ACID \& ETHYL ESTER) \\
\hline 100414 & ETHYL BENZENE \\
\hline 75003 & ETHYL CHLORIDE (CHLOROETHANE) \\
\hline 541413 & ETHYL CHLOROFORMATE \\
\hline 74851 & ETHYLENE \\
\hline 107211 & ETHYLENE GLYCOL \\
\hline 75218 & ETHYLENE OXIDE \\
\hline 96457 & ETHYLENE THIOUREA (2-IMIDAZOLIDINETHIONE) \\
\hline 151564 & ETHYLENEIMINE \\
\hline 2164172 & FLUOMETURON \\
\hline 50000 & FORMALDEHYDE \\
\hline 76448 & HEPTACHLOR \\
\hline 87683 & HEXACHLORO-1,3-BUTADIENE \\
\hline 118741 & HEXACHLOROBENZENE \\
\hline 77474 & HEXACHLOROCYCLOPENTADIENE \\
\hline 67721 & HEXACHLOROETHANE \\
\hline 1335871 & HEXACHLORONAPHTHALENE \\
\hline 680319 & HEXAMETHYL PHOSPHORAMIDE \\
\hline 302012 & HYDRAZINE \\
\hline 10034932 & HYDRAZINE SULFATE \\
\hline 7647010 & HYDROCHLORIC ACID (HYDROGEN CHLORIDE) \\
\hline 74908 & HYDROGEN CYANIDE \\
\hline 7664393 & HYDROGEN FLUORIDE (HYDROFLUORIC ACID) \\
\hline 123319 & HYDROQUINONE (DIHYDROXYBENZENE) \\
\hline 78842 & ISOBUTYRALDEHYDE \\
\hline 67630 & ISOPROPYL ALCOHOL (MANUFACTURING, STRONG-ACID PROCESS ONLY, NO PROCESS) \\
\hline 7439921 & LEAD \\
\hline 58899 & LINDANE (HEXACHLOROCYCLOHEXANE-gamma) \\
\hline 108316 & MALEIC ANHYDRIDE \\
\hline 12427382 & MANEB \\
\hline 7439965 & MANGANESE \\
\hline 108781 & MELAMINE \\
\hline 7439976 & MERCURY \\
\hline 67561 & METHANOL (METHYL ALCOHOL) \\
\hline 72435 & METHOXYCHLOR \\
\hline 96333 & METHYL ACRYLATE \\
\hline 74839 & METHYL BROMIDE (BROMOMETHANE) \\
\hline 74873 & METHYL CHLORIDE \\
\hline 78933 & METHYL ETHYL KETONE (MEK; 2-BUTANONE) \\
\hline 60344 & METHYL HYDRAZINE \\
\hline 74884 & METHYL IODIDE \\
\hline 108101 & METHYL ISOBUTYL KETONE (HEXONE) \\
\hline
\end{tabular}




\begin{tabular}{|c|c|}
\hline CAS & Substance \\
\hline 624839 & METHYL ISOCYANATE \\
\hline 80626 & METHYL METHACRYLATE (METHACRYLIC ACID METHYL ESTER) \\
\hline 101688 & METHYLENE BISPHENYL ISOCYANATE (DIPHENYLMETHANE-4,4'-DIISOCYANATE; MDI) \\
\hline 74953 & METHYLENE BROMIDE \\
\hline$\overline{1634044}$ & METHYL-TERT-BUTYL ETHER \\
\hline 90948 & MICHLER'S KETONE \\
\hline 1313275 & MOLYBDENUM TRIOXIDE \\
\hline 505602 & MUSTARD GAS (2,2'-DICHLORODIETHYL SULFIDE) \\
\hline 91203 & NAPHTHALENE \\
\hline 134327 & NAPHTHYLAMINE (ALPHA or 2-NAPHTHYLAMINE) \\
\hline 91598 & NAPHTHYLAMINE (BETA or 2-NAPHTHYLAMINE) \\
\hline 71363 & N-BUTANOL (N-BUTYL ALCOHOL) \\
\hline 7440020 & NICKEL \\
\hline 7697372 & NITRIC ACID \\
\hline 139139 & NITRILOTRIACETIC ACID \\
\hline 98953 & NITROBENZENE \\
\hline 1836755 & NITROFEN \\
\hline 51752 & NITROGEN MUSTARD (N-METHYL-BIS(2-CHLOROETHYL)AMINE) \\
\hline 55630 & NITROGLYCERIN (NG) \\
\hline 156105 & NITROSODIPHENYLAMINE (P-ISOMER) \\
\hline 55185 & N-NITROSODIETHYLAMINE (NDEA) \\
\hline 62759 & N-NITROSODIMETHYLAMINE (N,N-DIMETHYLNITROSOAMINE) \\
\hline 924163 & N-NITROSODI-N-BUTYLAMINE (DBN) \\
\hline 621647 & N-NITROSODI-N-PROPYLAMINE (NDPA) \\
\hline 86306 & N-NITROSODIPHENYLAMINE \\
\hline 4549400 & N-NITROSOMETHYLVINYLAMNE \\
\hline 59892 & N-NITROSOMORPHOLINE (NMOR) \\
\hline 759739 & N-NITROSO-N-ETHYLUREA \\
\hline 684935 & N-NITROSO-N-METHYLUREA \\
\hline 16543558 & N-NITROSONORNICOTINE \\
\hline 100754 & N-NITROSOPIPERIDINE (NPIP) \\
\hline 2234131 & OCTACHLORONAPHTHALENE \\
\hline 20816120 & OSMIUM TETROXIDE \\
\hline 56382 & PARATHION \\
\hline 87865 & PENTACHLOROPHENOL \\
\hline 79210 & PERACETIC ACID \\
\hline 108952 & PHENOL \\
\hline 106503 & PHENYLENEDIAMINE (P-ISOMER) \\
\hline 75445 & PHOSGENE (CARBONYL CHLORIDE) \\
\hline 7664382 & PHOSPHORIC ACID \\
\hline 7723140 & PHOSPHORUS (YELLOW OR WHTTE) \\
\hline 85449 & PHTHALIC ANHYDRIDE \\
\hline 88891 & PICRIC ACID $(2,4,6$-TRINITROPHENOL) \\
\hline 1336363 & POLYCHLORINATED BIPHENYLS (CHLORODIPHENYLS, 54\% CHLORINE) \\
\hline 1120714 & PROPANE SULTONE, $1,3-$ \\
\hline 57578 & PROPIOLACTONE (BETA-PROPIOLACTONE) \\
\hline 123386 & PROPIONALDEHYDE \\
\hline 114261 & PROPOXUR (BAYGON) \\
\hline 115071 & PROPYLENE \\
\hline 75569 & PROPYLENE OXIDE (1,2-EPOXYPROPANE) \\
\hline 75558 & PROPYLENEIMINE (2-METHYLAZIRIDINE) \\
\hline 110861 & PYRIDINE \\
\hline 91225 & QUINOLINE \\
\hline 106514 & QUINONE (P-BENZOQUINONE) \\
\hline
\end{tabular}




\begin{tabular}{|c|c|}
\hline $\mathbf{C A S}$ & Substance \\
\hline 82688 & QUNNTOZENE (PENTACHLORONITROBENZENE) \\
\hline 81072 & SACCHARIN (MANUFACTURING ONLY, NO PROCESSOR REPORTING) \\
\hline 94597 & SAFROLE \\
\hline 7782492 & SELENIUM \\
\hline 7440224 & SILVER \\
\hline 1310732 & SODIUM HYDROXIDE (SOLUTTION) \\
\hline 7757826 & SODIUM SULFATE (SOLUTION) \\
\hline 100425 & STYRENE (PHENYLETHYLENE; VINYL BENZENE) \\
\hline 96093 & STYRENE OXIDE \\
\hline 7664939 & SULFURIC ACID \\
\hline 100210 & TEREPHTHALIC ACID \\
\hline 127184 & TETRACHLOROETHYLENE (PERCHLOROETHYLENE) \\
\hline 961115 & TETRACHLORVINPHOS (STIROFOS) \\
\hline 7440280 & THALLIUM \\
\hline 62555 & THIOACETAMIDE \\
\hline 62566 & THIOUREA \\
\hline 1314201 & THORIUM DIOXIDE \\
\hline 13463677 & TITANIUM DIOXIDE \\
\hline 7550450 & TITANIUM TETRACHLORIDE \\
\hline 108883 & TOLUENE (TOLUOL) \\
\hline 584849 & TOLUENE-2,4-DIISOCYANATE (TDI) \\
\hline 91087 & TOLUENE-2,6-DIISOCYANATE \\
\hline 95534 & TOLUIDINE (O-ISOMER) \\
\hline 636215 & TOLUIDINE HYDROCHLORIDE (O-ISOMER) \\
\hline 8001352 & TOXAPHENE (CHLORINATED CAMPHENE) \\
\hline 68768 & TRIAZIQUONE \\
\hline 52686 & TRICHLORFON \\
\hline 79016 & TRICHLOROETHYLENE \\
\hline 1582098 & TRIFLURALIN (2,6-DINITRO-N,N-DIPROPYL-4-(TRIFLUOROMETHYL) BENZENAMINE) \\
\hline 126727 & TRIS(2,3-DIBROMOPROPYL) PHOSPHATE \\
\hline 51796 & URETHANE (CARBAMIC ACID, ETHYL ESTER) \\
\hline 1314621 & VANADIUM (PENTAOXIDE; FUME OR DUST) \\
\hline 108054 & VINYL ACETATE \\
\hline 593602 & VINYL BROMIDE (BROMOETHENE) \\
\hline 75014 & VINYL CHLORIDE \\
\hline 75354 & VINYLIDENE CHLORIDE (1,1-DICHLOROETHYLENE) \\
\hline 108383 & XYLENE (M-ISOMER) \\
\hline 1330207 & XYLENE (MIXED ISOMERS) \\
\hline 95476 & XYLENE (O-ISOMER) \\
\hline 106423 & XYLENE (P-ISOMER) \\
\hline 1314132 & ZINC OXIDE (FUME OR DUST) \\
\hline 12122677 & ZINEB \\
\hline
\end{tabular}




\section{Policy Research Working Paper Series}

Title

WPS1979 Banking on Crises: Expensive Lessons from Recent Financial Crises

WPS1980 The Effect of Household Wealth on Educational Attainment: Demographic and Health Survey Evidence

WPS1981 Evaluating Public Expenditures When Governments Must Rely on Distortionary Taxation

WPS1982 Analyzing Financial Sectors in Transition: With Special Reference to the Former Soviet Union

WPS1983 Pension Reform in Small Developing Countries

WPS1984 NAFTA, Capital Mobility, and Mexico's Financial System

WPS1985 The Optimality of Being Efficient: Designing Auctions

WPS1986 Putting Auction Theory to Work: The Simultaneous Ascending Auction

WPS1987 Political Economy and Political Risks of Institutional Reform in the Water Sector

WPS1988 The Informal Sector, Firm Dynamics, and Institutional Participation

WPS1989 Contingent Government Liabilities: A Hidden Risk for Fiscal Stability

WPS1990 The East Asia Crisis and Corporate Finances: The Untold Micro Story

WPS1991 Reducing Air Pollution from Urban Passenger Transport: A Framework for Policy Analysis

WPS1992 The Present Outlook for Trade Negotiations in the World Trade Organization
Author

Date

Gerard Caprio, Jr.

September 1998

Deon Filmer

Lant Pritchett

September 1998

James E. Anderson

Will Martin

September 1998

L. Tabada 36896
Alan Roe
Paul Siegelbaum
Tim King

September 1998

Thomas Charles Glaessner September 1998

Salvador Valdés-Prieto

Thomas Charles Glaessner September 1998 Daniel Oks

September 1998

Lawrence M. Ausubel

Peter Cramton

Paul Milgrom

Ariel Dinar

Trichur K. Balakrishnan Joseph 'Wambia

Alec R. Levenson

William F. Maloney

Hana Polackova

Michael Pomerleano

Mark Heil

Sheoli Pargal

September 1998

September 1998

M. Navarro

84722

M. Navarro

84722

S. Vivas

82809

S. Vivas

82809

F. Toppin

30450

September 1998

T. Gomez 32127

October 1998

A. Panton 85433

October 1998

N. Dacanay 34068

October 1998

R. Yazigi

37176

John Croome

October 1998
L. Tabada 36896 


\section{Policy Research Working Paper Series}

\section{Title}

Author

Date

Contact

WPS1993 Financial Safety Nets and Incentive
Structures in Latin America
$\begin{aligned} & \text { WPS1994 Estimating Wealth Effects without } \\ & \text { Expenditure Data - or Tears: } \\ & \text { with an Application to Educational } \\ & \text { Enrollments in States of India }\end{aligned}$
WPS1995 What Macroeconomic Policies
Are "Sound?"
WPS1996 Namibia's Social Safety Net:
Issues and Options for Reform
WPS1997 On Measuring Literacy

Philip L. Brock

Deon Filmer

Lant Pritchett

October 1998

for paper

Mansoor Dailami

Nadeem ul Haque

October 1998

B. Nedrow

Kalinidhi Subbarao

October 1998 31585

Kaushik Basu

James E. Foster

October 1998

K. Labrie 38256

October 1998

S. Fallon 38009

WPS1998 The Structure and Determinants of Inequality and Poverty Reduction in Ghana, 1988-92

Sudharshan Canagarajah Dipak Mazumdar Xiao Ye

WPS1999 Heterogeneity among Mexico's Micro-Enterprises: An Application

Wendy V. Cunningham William F. Maloney of Factor and Cluster Analysis

WPS2000 GATT Experience with Safeguards: Making Economic and Political

J. Michael Finger

Sense of the Possibilities that the GATT Allows to Restrict imports

WPS2001 Measuring the Dynamic Gains from Trade

Romain Wacziarg

October 1998

October 1998

T. Gomez

November 1998

S. Crow 30763

38400

32127

October 1998

L. Tabada 36896 